\title{
Explaining Trade Flows: Traditional and New Determinants of Trade Patterns
}

\author{
Julien Gourdon \\ World Bank \\ CERDI
}

\begin{abstract}
An empirical tradition in international trade seeks to establish whether the predictions of factor abundance theory match with the data. In this paper, we test if the "new" determinants used in the factor content version of $\mathrm{H}-\mathrm{O}-\mathrm{V}$ models (differences in productivity, in returns to scale or in consumers' preferences) help us to improve our estimation of trade patterns in commodities. The results show that conventional factors are still important in determining trade structure although new determinants need to be included to determine comparative advantage. Turning to the change across periods, differences in factor endowments have not diminished over time: we observe an increase in specialization according to skill endowment. Hence, those "new" determinants are not new forces that drive trade flows.
\end{abstract}

- JEL Classification : F11, F14, F2

- Key Words: international trade, Hecksher-Ohlin model

\section{Introduction}

In the neo-classical general equilibrium model of international trade, countries trade with each other because of their differences. The Heckscher-Ohlin model, developed by Eli Heckscher and Bertil Ohlin, holds on to the idea that trade patterns depend on the relative differences of countries' factor endowments.

\footnotetext{
*Corresponding address: Julien Gourdon: The World Bank, 1818 H Street, NW, Washington, DC 20433 USA, CERDI, Clermont-Ferrand, Fance, e-mail: jgourdon@worldbank.org 
Empirical studies, however, have often shown a weak link between factor endowments and trade flows, both within countries (between regions) and between them. Those studies have tested two versions of the H-O model: the commodity version and the factor content version. In the commodity version, a capitalabundant country will export capital-intensive goods. In the generalization of a factor version (Vanek, 1968), a capital-abundant country will export capital services.

Many improvements on the factor content version have been introduced and tested, but their implications concerning net trade in commodities seem relatively weak. ${ }^{1}$ Predicting net trade in commodities in an nxn world is not straightforward, notably because input-output linkages preclude a linear relation between factor endowments and net exports. Furthermore, unlike in the Ricardian model, in the HO model a ladder of comparative advantage cannot be obtained. This paper is a contribution to the body of literature on trade patterns of developing countries.

The Heckscher-Ohlin-Vanek (H-O-V) theorem has been frequently rejected in favor of statistical hypotheses such as a zero correlation between factor endowments and trade patterns. The prevailing view in the mid-1990's shaped by unclear results, can be encapsulated by Leamer and Levinsohn's appraisal (1995) of the empirical performance of factor endowment theories: "It is more convenient to estimate the speed of arbitrage rather than test if the arbitrage is perfect and instantaneous".

During the same period, an expanding body of literature on the determinants of trade patterns used differences in consumers' preferences, technology, or returns to scale. Differences in technology, suggested by Ricardo, have been frequently used (Trefler 1995, Davis and Weinstein 2001) and, not surprisingly, have considerably improved the prediction of trade in factor services. On the other hand, differences in consumer's preferences could relate to home bias consumption (Trefler 1995) or non-homothetic preferences due to differences in income per capita (Markusen 1986 or Jones et al. 1999). Finally, increasing returns to scale in some sectors is also relevant in explaining some factor service trade flows (Antweiler and Trefler 2002, Head and Ries 2001).

To learn more about the determinants of comparative advantage one needs to include many countries and, if possible, over a sufficiently long period of time, to

'There are also improvements concerning the literature on specialization in production: some authors (e.g. Harrigan 1997) argue that it is more important to look at the pattern of specialization rather than the pattern of trade since economists won't be able to understand trade until they understand specialization. 
observe if those determinants have changed through time. In the absence of reliable input-output data needed to compute the net factor content of trade, one can study the determinants of net trade in commodities (i.e. rely on the commodity version of the H-O-V theorem). Lederman and Xu (2001) include these "new" determinants in a commodity version for a panel of 57 countries over 25 years for 10 products' clusters introduced by Leamer (1984). They used a probit estimation to test the impact of factor endowments on net exports which is a better way of controling for non-linearity than the one used in previous commodity studies (Leamer 1984 and 1987).

This paper extends the commodity version analysis in several ways. First, it includes differences in consumers' preferences and differences in returns to scale as determinants of comparative advantage and not only as determinants of trade intensity. Second, total factor productivity is used as a measure for differences in technology, rather than expenditure in research and development. Third, a sample of 71 countries over 40 years (see Table A1. in Appendices) makes it possible to discern two periods: pre-1980 and post-1980, and isolate any changes in the relative importance of conventional and new factors during the period under review. Fourth, we use a more disaggregated classification than Leamer, leading to better results on manufactured commodities. ${ }^{2}$ Finally, rather than using "unadjusted" factor endowments measures, we use a measure of relative factor endowment (relative to the world endowment) in order to be closer to the theory.

The results show that the H-O-V is "alive and well" and, furthermore, the "new" determinants do not have a greater explanatory power in the 1980-2000 period than they do in the 1960-1980 period. Nonetheless, adding the new determinants of factor content studies helps us improve the prediction of specialization in different manufactured products. Similar results have been found in previous studies. The importance of factor endowments is especially strong concerning specialization in the human capital endowment. This finding may come as a result of distinguishing among three sets of skills: unskilled, primary skilled, and highly skilled. Trade patterns are also determined by trade intensity; here difference in technology, trade policy, transport, and transaction costs explain the difference in trade intensity.

The paper is organized as follows. Section II provides an overview of the H-O model and the amendments added in the factor content studies. Section III describes the empirical approach, the data used and their organization between

${ }^{2}$ The manufactured commodities' clusters are more detailed. 
explanatory variables for comparative advantage and for trade intensity, and the cluster's construction. Section IV presents the econometric results followed by section $\mathrm{V}$, which concludes.

\section{Theoretical Approaches to Explain Trade Patterns}

The traditional explanation of trade based on the $\mathrm{H}-\mathrm{O}$ theorem states that under perfect competition, identical technology, identical and homothetic tastes, and no impediments to trade, net trade for country $c, T^{c}$ is a linear function of technology, $A$, consumption share $s_{\left(y_{c}\right)}^{c}$ and factor endowment $V^{c}$, according to the well-known relation:

$$
p T^{c}=w A^{-1}\left(V^{c}-s^{c} V^{w}\right) \text { with } A w=p \text { and } p \equiv w \equiv 1
$$

where $w$ stands for the vector of factor prices and $p$ stands for the vector of commodity prices which are set equal to unity by choice of units.

Several studies linking the pattern of trade (i.e. net exports) to endowments have found the relation to be non-linear. More recent investigations have relaxed the above "strict" formulation by allowing for "new" determinants: (i) differences in total factor productivity (TFP) taking place at the country level, which are captured by scaling the endowment vector at the country level $\delta^{c}$; (ii) economies of scale at the industry level, $\mu$; (iii) identical, but quasi-homothetic preferences so that consumption shares are a function of income per capita y, i.e $s_{\left(y_{c}\right)}^{c}$

$$
T^{c}(\mu)=A^{-1}\left(\delta^{c} V^{c}-s_{\left(y_{c}\right)}^{c} V^{w}\right)
$$

Frictions (trade barriers, ${ }^{3}$ transaction and transport costs) should also be taken into account. As Leamer (1984) showed, these impediments are reflected in a deviation of domestic prices from international prices. In matrix notation, let $\theta$ subscript indicate variables that depend on trade impediments. Then, the zero profit condition $A w=p$ becomes $A_{\theta} W_{\theta}=\theta p^{w}=p_{\theta}$. We may then write the trade vector in value terms as:

$$
p_{\theta} T^{c}(\mu)=A_{\theta}^{-1}\left(w_{\theta} \delta^{c} V^{c}-s_{\theta\left(y_{c}\right)}^{c} w_{w} V^{w}\right)
$$

Typically, to include new determinants, these extensions are introduced in factor content version. In this paper, we take the view that investigating the $\mathrm{H}-\mathrm{O}$

${ }^{3}$ Travis (1964) argues that tariffs on labor intensive imports can explain the Leontief finding that US in 1947 was net exporter of labor services. 
"theorem" is best done by studying net export patterns rather than the factor content - which requires input-output (IO) matrices ${ }^{4}$ - or the industrial version which is further away from $\mathrm{H}-\mathrm{O} .^{5}$

Using new determinants found in factor content versions in a commodity version, allows us to learn more about the determinants of comparative advantage. As noted earlier in the paper, a study like this needs to include many countries and, if possible, over a sufficiently long period of time in order to observe possible changes in determinants through time. In the absence of reliable input-output data needed to compute the net factor content of trade, one may study the determinants of net trade on commodities.

\section{Empirical Approach}

We model export intensity as a Heckman selection model. That is, countryspecific characteristics or factor endowments determine comparative advantage proxied by the condition of having positive net exports - on one hand, and domestic and foreign market sizes, the macroeconomic environment, transaction costs, and institutions determine export intensity, on the other hand. Moreover, we allow the estimates of trade intensity for the net-importer and the net-exporter subsamples to differ.

\section{A. Selection Model}

To implement equation (3) one could regress the net exports of a country $c$ for a product $i$ in year $t, N X_{i c t}$, on endowment in different factors $j, E_{j c t}$, on $k$ new determinants (difference in productivity, in consumers preferences and returns to scale) $N_{k c t}$, on $m$ variables determining trade intensity (or impediments) $T l_{m c t}$ and on regional dummies $D R_{r t}$ and year dummies $D Y_{t}$ in the following way:

$$
N X_{i c t}=\beta_{0}+\sum_{j=1,5} \beta_{1 j} E_{j c t}+\sum_{k=1,3} \beta_{2 k} N_{m c t}+\sum_{m=1,5} \beta_{3 M} T I_{m c t}+D R_{r t}+D Y_{t}+\varepsilon_{c t}
$$

However, trade impediment variables do not have the same impact on net trade for net importers and net exporters since trade liberalization increases the net trade ratio for net importers and decreases the net trade ratio for net exporters. In other

\footnotetext{
${ }^{4}$ They often cover just one year, or do not use real input output matrix from all countries, or do not account for natural resources.

${ }^{5}$ The H-O theorem is based on international trade and data on production by sector is less available than data on trade by sector, so the sample of countries is often small.
} 
words, it is unlikely that the coefficients of the explanatory variables for trade intensity are the same for all countries, especially for importing and exporting countries of the same commodity. In a linear homogenous implementation, the effects of many variables would be washed out by this heterogeneity.

Moreover, the initial presumed linear relationship between factor endowments and the structure of net exports is questionable (Leamer 1984, Leamer et Levinsohn 1995). Effectively, all countries do not produce all goods, particularly developing countries. An increase in capital endowment would not lead to an increase in capital-intensive good exports if the country is already specialized in a non capital-intensive good or does not product any capital-intensive goods. We present our data in Figure 1, which plots net exports of a labor-intensive aggregate divided by the country's workforce against the country's overall capital/labor ratio. There is very clear evidence of non-linearity here - countries which are very scarce in capital do not trade much these products. Exports start to emerge when the capital/labor abundance ratio is around US $\$ 20,000$ per worker. Thereafter, net exports steadily decline, turning negative when the country's capital/labor abundance ratio is around US $\$ 40,000$. Hence, an increase in capital per worker has no effect on specialization if such an increase does not reach a certain threshold.

Figure 1. Non-linearity Between Factor Endowment and Net Exports

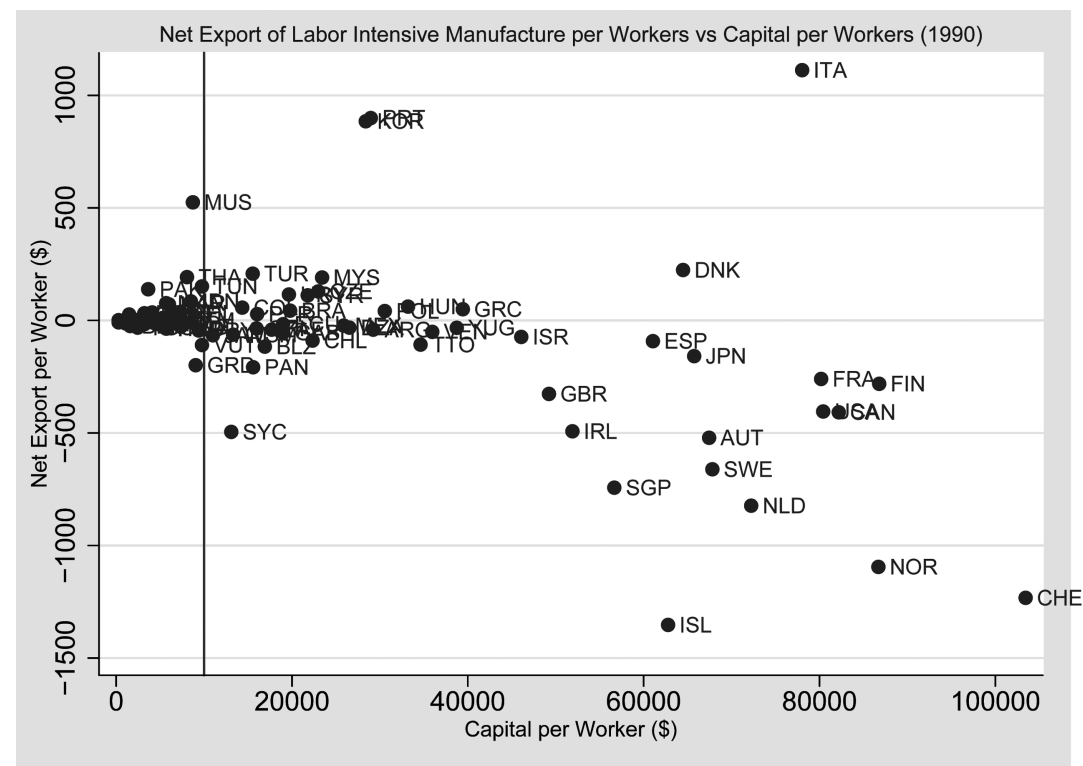


To control for the heterogeneity in the trade impediment variables, we can have the trade intensity variables interact with a dummy, indicating the status $S_{c t}$ of the country (where 1 indicates a net exporter status and 0 a net importer status).

Using a probit estimation for the status allows a non-linear relationship between factor endowment and the net export, meaning that the marginal impact of an increase in factor endowment is greater when the factor endowment is already sufficiently high to allow countries to specialize in the good. An estimable model would have the following form:

$$
N X_{i c t}=\beta_{0}+\sum_{k=1,3} \beta_{1 k} N_{k c t}+\sum_{m=1,5} \beta_{2 M}\left(S_{c t} * T I_{m c t}\right)+\sum_{m=1,5} \beta_{3 M} T I_{m c t}+\beta_{4 M} S_{c r}+D Y_{t}+\varepsilon_{c t}
$$

where $S_{c t}=\alpha_{0}+\sum_{j=1,5} \alpha_{1 j} E_{j c t}+\sum_{k=1,3} \alpha_{2 k} N_{k c t}+D R_{r t}+D Y_{t}+\mu_{c t} \quad$ with $\beta_{2}>0$ and $\beta_{3}<0$

With a linear estimation, we would have biased results in case of correlation between $\varepsilon_{c t}$ and $\mu_{c t}$. It is plausible that the unobservable variables for the status would be correlated with unobservable variables for the amount of net exports. Following Lederman and Xu (2001), we use a Heckman procedure to control for that. We initially test in equation (6) the probability of being a net exporter of a good (i.e. the status). We assume that the probability of having positive net exports $S_{c t}$ is determined by the conventional explanatory variables, factor endowments, $E_{j c t}$, and by "new" determinants $N_{k c t}$. We assume increasing returns to scale and TFP should lead to be net exporter of manufactured products, at the expanse non manufacture products. Differences in consumers' preferences are also potentials determinants in this comparative advantage equation since theory suggests that demand for superior goods increases as income rises, whereas demand falls for an inferior good. So we expect that a rise in income par capita will decrease the probability of being a net importer in superior goods since this will increase imports and/or decrease exports of superior goods to respond to the local demand. Moreover, some determinants of trade intensity $T I_{m c t}$ (e.g. infrastructure and information and communication technology-ICT) could also determine the comparative advantage, since products are differently sensitive to transport and transactions costs. ${ }^{6}$ Manufactured products and mainly most sophisticated

\footnotetext{
${ }^{6}$ In a Heckman procedure all determinants of the second step (here trade intensity variables) have to be included in the first step if they are significant in this first step. The same variables that determine how big a country's net exports of a particular good (or commodity group) also determine that probability that a country will export these goods at all.
} 
manufactures should be more sensitive to ICT. Bougheas and al (2000) showed that increasing infrastructure tends to raise the specialization in manufacture products since it could be considered as a cost-reducing technology for the manufactured sector.

$$
S_{c t}=\alpha_{0}+\sum_{j=1,5} \alpha_{1 j} E_{j c t}+\sum_{m=1,3} \alpha_{2 k} N_{k c t}+\sum_{m=1,2} \alpha_{3 m} T I_{m c t}+D R_{r t}+D Y_{t}+\mu_{c t}
$$

Following this, we continue by testing the explanatory variables on the samples of net exporters (equation 7) and net importers (equation 8) relative to trade intensity. To the usual determinant of trade intensity, we add new determinants that are as important as in the comparative advantage estimate. We expect a significant importance of frictions (trade barriers, transaction and transport costs). The sign of variables capturing increasing returns to scale (total population) and consumers' preferences (income per capita) might be unclear since those variables might also capture size market effects. All those explanatory variables are presented in Appendices, Table A3.

$$
\begin{aligned}
& N X_{i c t}=\beta_{0}+\sum_{k=1,3} \beta_{1 k} N_{k c t}+\sum_{m=1,5} \beta_{2 M} T I_{m c t}+D Y_{t}+\varepsilon_{c t} \text { if } \mathrm{S}=1 \\
& N X_{i c t}=\beta_{0}+\sum_{k=1,3} \beta_{1 k} N_{k c t}+\sum_{m=1,5} \beta_{2 M} T I_{m c t}+D Y_{t}+\varepsilon_{c t} \text { if } \mathrm{S}=0
\end{aligned}
$$

Following Lederman and $\mathrm{Xu}$ (2001), we consider that factor endowments should not be added in the second step. Our justification is statistical, we see in Table A4 provided in the Appendices that the condition of being a net exporter has an even higher cross-country variance (column "between") relative to cross-time variance (column "within") than the value of net exports for most sectors. The relative factor endowment variables (in bold) are also relatively more stable over time than among countries. ${ }^{7}$

\section{B. Construction and Measure for Commodities' Clusters}

Our classification (Table A2. in the Appendices) is less detailed than Leamer's with regard to the categories of primary products for which the determinants of comparative advantage have often been estimated. We construct three clusters of

${ }^{7}$ Nevertheless we have run the second step including the factor endowments, the results for the factors endowment variables are not often significant, though they have the expected sign when significant. 
primary products, agricultural products (AGR), processed food products (PFO) and mineral products (MIN). We obtain five clusters for manufactured products: intensive in natural resources and capital (NRK), intensive in unskilled labor (UNL), intensive in skilled labor (SKL), intensive in capital (CAP), and intensive in technology (TEC). This level of detail is more precise compared to what the existing literature offers, and should allow us to obtain better results than using only a two digit classification.

\section{Construction and Measure for Factors Endowments}

The H-O model framework considers relative factor endowments among many factors but also among many countries. It is more suitable to use a ratio of a country's per capita endowment of a factor to the world per capita endowment of that factor as we deal with relative advantage in factor endowments (Harrigan and Zakrajsek, 2002). We use the formula constructed by Spilimbergo et al. (1999). ${ }^{8}$ The ratios are weighted by the degree of openness to take into account that endowments of closed countries do not compete in the world markets with other factors.

To measure human capital endowment, we prefer to use an educational-based classification rather than an occupational-based one for the reasons exposed by Harrigan (1997). In contrast to Estervadeordal (1997) or Schott (2003) who used only the distinction between skilled and unskilled workers, we use, like Harrigan (1997) three sets of skills: unskilled, primary skilled, and highly skilled.

The well-known Ethier-Svensson-Gaisford (ESG) model with mobile (capital) and immobile (land and labor) factors shows that capital is a determinant of pattern of trade for a country, depending on capital intensity of the goods in which its immobile factors give it a comparative advantage. Following Leamer (1999), we adopt the Kraay et al. (1999) measure of capital stock per worker.

The measure for natural resources endowment is arable land per inhabitant, so our measure does not include mineral and fuel resources which are not available for a large sample in the period under review.

\footnotetext{
${ }^{8} E_{i f}$ is the endowment of country $\mathrm{i}$ in factor $\mathrm{f}$ and the measure of relative endowment is $R E_{i f}=\operatorname{In} \frac{\left(E_{i f}\right)}{\left(E_{f}^{*}\right)}$ and $E_{f}^{*}=\frac{\sum_{i}\left(E_{i f} \times p o p_{i} \times\left(\frac{X+M}{G D P}\right)\right)}{\sum_{i}\left(\operatorname{pop}_{i} \times\left(\frac{X+M}{G D P}\right)\right)_{i}}$
} 


\section{Construction and Measure of "New" Determinants of Trade}

Concerning differences in technology, we measure total factor productivity (TFP). This measure was used by Harrigan (1997) to explain how differences in technology associated with factor endowments could help explain specialization in production. We construct a TFP index from our dataset as the residual of a growth regression (assuming increasing returns to scale ${ }^{9}$ ). We use a proxy of scale economic effect that could lead the country to be specialized in some increasing returns to scale sectors, measured by the number of habitants. We also control for differences in consumer's preferences via income per inhabitant, since an increase of per capita income should lead the consumer to prefer physical and human capital intensive goods and hence to be a net importer of those products.

\section{E. Construction and Measure of Trade Intensity Explanatory Variables}

Variables that determine trade intensity can be separated in two groups: structural variables and political variables. The first set of variables represents lanlockness of the country, the demand of its partners (proxied by the average rate of growth of main partners) and the size of its domestic market, which is measured by population and GDP per inhabitant. Domestic transport infrastructure and transaction costs determine the amount that a country exports or imports. For those variables, we use an index constructed as a principal component: road networks, rail networks, and paved road for the infrastructure index; and personal computer, internet host, telephone lines, and mobile phones for the ICT index. Finally, openness depends on the degree of outwardness of the country. We measure this position by an indicator carefully computed by Wacziarg and Welch (2003), which is a dummy variable taking value 0 or 1 depending on liberalization.

\section{Results}

The main objective of this study is to improve the prediction of patterns of trade. So we have to assess the reliability of the prediction of export/import status for

${ }^{9}$ We get the $\alpha$ and $\beta$ from the following classical growth equation on our sample $\operatorname{Ln}\left(\frac{Y}{L}\right)=\alpha \operatorname{Ln}\left(\frac{K}{L}\right)+\beta \operatorname{Ln}\left[\frac{H \cdot L}{L}\right]+\mu_{i}+v_{t}+\varepsilon_{i, t}$ where $\mathrm{H}=(1.1)^{\text {yearsofschool }}$ which means that we relate human capital $(\mathrm{H})$ to average years of schooling fron Barro and Lee (2000) assuming a 10 percent return to each year. We get $\alpha=0.5$ and $\beta=0.7$. Then we calculate the TFP as TFP $=(\mathrm{Y} / \mathrm{L}) /(((\mathrm{K} / \mathrm{L}) \cdot 5) *(\mathrm{H} \cdot 7))$ 
each country. This is done in section IV.A. A substantial part of this study also deals with the importance of "new" determinants of comparative advantage. In section IV.B, using an Anova estimate, we compare the importance of the "new" determinants of comparative advantage relative to the traditional factors and analyze changes during two periods, 1960-1980 and 1980-2000. Subsequently, we interpret the results of the Heckman estimation. In section IV.C, we present results for the first step, the selection equation on comparative advantage, which is also estimated for the two periods noted earlier. The last section, IV.D, deals with the second step, the trade intensity, where we interpret the results on net exporters and net importers of each cluster. ${ }^{10}$

\section{A. Goodness of Fit}

One way to assess whether the model is fit is to concentrate on its predictive power by looking at prediction statistics. In the first part of table 1 we present the goodness of fit for a model with only factor endowments. In the second part, we add new factors - productivity differences, scale returns, and consumers' preferences - and in the last part we add ICT and infrastructure. For each part, the first column gives us the predictive success rate calculated with the sensitivity, percentage of positive sign (net exporter) correctly identified, and the specificity, percentage of negative sign (net importer) correctly identified. In the second column, we add a test which compares the predicted results to a random assignment. For the second and third parts, the third column presents the improvement in the goodness of fit (measured by the Fit test) compared to the previous part. For example, for the capital intensive cluster (CAP), accounting for new determinants improves the goodness of fit by $8 \%$, and if we account for difference in ICT and Infrastructure we improve the goodness of fit by $3 \%$.

We conclude that adding "new" determinants for trade patterns helps us improve the prediction of being a net exporter of manufactured products as well as minerals products. Improvement due to the inclusion of ICT and infrastructure seems to concern all clusters, and especially primary commodity cluster. As a comparison,

\footnotetext{
${ }^{10}$ Since we use generated variables (mills ratio, principal component index), we have to recalculate all the standard errors of this variables; to do this, and to construct the confidence intervals, we employ the bootstrap technique. For a generated variable, the confidence interval in the second step is not correct as it refers to the first step. So we built a sampling distribution based on the initial sample from which repeated sample are drawn to obtain a correct distribution and correct standards errors

${ }^{11}$ Proportion of observations for which excess in factor endowments and excess in factor content in net export have the same sign.
} 
Table 1. Quality of Prediction for the Comparative Advantage Model

\begin{tabular}{|c|c|c|c|c|c|c|c|c|}
\hline & \multicolumn{2}{|c|}{ 1: HOV } & \multicolumn{3}{|c|}{$\begin{array}{l}\text { 2: HOV }+ \text { New deter- } \\
\text { minants }\end{array}$} & \multicolumn{3}{|c|}{$\begin{array}{c}\text { 3: HOV + New } \\
\text { determ. + ICT-Infra- } \\
\text { structure }\end{array}$} \\
\hline & $\mathrm{Fit}^{\mathrm{a}}$ & $\mathrm{ROC}^{\mathrm{b}}$ & Fit & $\mathrm{ROC}$ & Impr. & Fit & $\mathrm{ROC}$ & Impr. \\
\hline Agricultural Products (AGR) & 70 & 76 & 70 & 76 & $0 \%$ & 74 & 78 & $6 \%$ \\
\hline Processed Food Products (PFO) & 70 & 72 & 70 & 74 & $0 \%$ & 72 & 76 & $3 \%$ \\
\hline Minerals Products (MIN) & 58 & 65 & 63 & 70 & $9 \%$ & 64 & 72 & $2 \%$ \\
\hline $\begin{array}{l}\text { Natural Resources-intensive } \\
\text { (NRK) }\end{array}$ & 62 & 71 & 64 & 74 & $3 \%$ & 65 & 75 & $2 \%$ \\
\hline Unskilled Labor-intensive (UNL) & 56 & 61 & 76 & 85 & $36 \%$ & 78 & 87 & $3 \%$ \\
\hline Skilled Labor-intensive (SKL) & 72 & 79 & 78 & 88 & $8 \%$ & 78 & 89 & $0 \%$ \\
\hline Capital-intensive (CAP) & 71 & 85 & 77 & 90 & $8 \%$ & 79 & 90 & $3 \%$ \\
\hline Technological Products (TEC) & 85 & 93 & 86 & 93 & $1 \%$ & 89 & 97 & $3 \%$ \\
\hline
\end{tabular}

Notes: ${ }^{\text {a }}$ Proportion of correct sign prediction for net exporters and net importers (with the mean of predicted probability as cutoff).

${ }^{\mathrm{b}}$ Receiver Operating Characteristics: Compared to a random prediction (50 means that the model doesn't do any better that random assignment would).

in Bowen et al. (1987) the sign test ${ }^{11}$ is around 0.6, which depends on factors. Trefler (1995) with the sign test improves his model from 0.71 (conventional factors) to 0.93 (conventional and "new" determinants). Davis and Weinstein (2001) with the same test improve their model from 0.32 to 0.91 . Antweiler and Trefler (2002) obtained a sign test of 0.67 with a strict $\mathrm{H}-\mathrm{O}-\mathrm{V}$ model and 0.66 with a modification taking into account returns to scale. Here, the percentage of signs correctly identified depends on sectors; the"new" determinants do not improve the ROC test for primary and high technology products.

Due to the presence of a number of potentially collinear variables in the first step, we implement the variance inflation factor test (VIF). The literature states that for an indication of multicolinearity to exist, the value that indicates the highest VIF should be greater than 5 . In this study, we obtain 4.7 which suggest that multicolinearity is not a serious problem.

\section{B. Conventional Factors Versus "New" Factors: ANOVA Estimates}

As noted in the ANOVA exercise, ${ }^{12}$ the role of conventional factors in accounting for patterns of comparative advantage is still important when predicting the probability of a country being a net exporter of a product (in table 2). Nevertheless, when it comes to certain industrial products, new factors could be more relevant in explaining the structure of trade. In conventional factors we 
distinguish between capital and land on one hand, and human capital on the other hand, which is sometimes analyzed as a non-conventional factor. We perform this test on two periods, 1960-1980 and 1980-2000.

As we could expect, physical capital endowment is not the main determinant to explain the choice of specialization across industrial clusters. Because of its mobility, a country which has more capital may prefer to transfer it in another country via FDI rather than invest it in a more capital intensive production. In the same way, a country which is relatively less endowed with physical capital could produce more capital-intensive goods via FDI from another country. Generally, for primary products, the share of traditional factors is greater than the share of new determinants, while the opposite is true for manufactured goods. The main conclusion about the decomposition in two periods is that, effectively, conventional factors are not the only determinants of trade patterns, but they were as determining as ever during the specialization that took place during the least twenty years. Land abundance is particularly more determining in the last period for primary products, because of the emergence of land-abundant developing countries in international trade.

We now turn ourselves toward the Heckman procedure described in equation (6) to (8). Expected results are presented in Appendices, Table A5.

\section{Comparative Advantage}

\section{(1) The role of conventional factors}

Concerning natural resources, results are encouraging because of the positive and significant sign for the probability of being a net exporter of AGR, PFO, and NRK products. The results in table 3 imply that a one percent increase in the relative endowment in arable land is associated with an increase of $0.308 \%$ in the probability of being a net exporter of PFO (column 2) and $0.28 \%$ increase in the probability of being a net exporter of NRK (column 4). These results confirm earlier estimates by Leamer (1984), Estervadeordal (1997), and Lederman and Xu (2001). The non-significance for MIN (column 3) may be due to the missspecification of endowment in mineral resources; we just measure endowment in arable land. The negative coefficient for land abundance concerning TEC (column 8) conforms to Leamer's view (1999) that countries relatively abundant in land will

\footnotetext{
${ }^{12} \mathrm{We}$ report the range of the variance of comparative advantage attributable to traditional factors and to "new" factors.
} 
Table 2. Role of Conventional and New Factors in Explaining the Predicted Probability

\begin{tabular}{|c|c|c|c|c|c|c|}
\hline $\begin{array}{c}\text { Share of Variance } \\
\text { Explained by: }\end{array}$ & Period & $\begin{array}{c}\text { Land and } \\
\text { Capital }\end{array}$ & $\begin{array}{l}\text { Human } \\
\text { Capital }\end{array}$ & New & ICT-Infra & R-squared \\
\hline Agricultural Products & $1960-2000$ & $44 \%$ & $32 \%$ & $4 \%$ & $21 \%$ & 98 \\
\hline \multirow[t]{2}{*}{ AGR } & $1960-1980$ & $35 \%$ & $15 \%$ & $3 \%$ & $47 \%$ & \\
\hline & $1980-2000$ & $41 \%$ & $40 \%$ & $13 \%$ & $7 \%$ & \\
\hline Processed Food & $1960-2000$ & $48 \%$ & $37 \%$ & $11 \%$ & $4 \%$ & 96 \\
\hline \multirow[t]{2}{*}{ PFO } & $1960-1980$ & $44 \%$ & $41 \%$ & $10 \%$ & $5 \%$ & \\
\hline & $1980-2000$ & $47 \%$ & $41 \%$ & $10 \%$ & $3 \%$ & \\
\hline Minerals (raw, without oil) & $1960-2000$ & $39 \%$ & $39 \%$ & $8 \%$ & $14 \%$ & 99 \\
\hline \multirow[t]{2}{*}{ MIN } & $1960-1980$ & $25 \%$ & $56 \%$ & $4 \%$ & $16 \%$ & \\
\hline & $1980-2000$ & $47 \%$ & $17 \%$ & $7 \%$ & $30 \%$ & \\
\hline $\begin{array}{l}\text { Natural Resources } \\
\text { Intensive }\end{array}$ & $1960-2000$ & $54 \%$ & $32 \%$ & $6 \%$ & $8 \%$ & 91 \\
\hline \multirow[t]{2}{*}{ NRK } & $1960-1980$ & $27 \%$ & $37 \%$ & $10 \%$ & $25 \%$ & \\
\hline & $1980-2000$ & $50 \%$ & $33 \%$ & $4 \%$ & $13 \%$ & \\
\hline Unskilled Labor Intensive & $1960-2000$ & $5 \%$ & $17 \%$ & $65 \%$ & $13 \%$ & 88 \\
\hline \multirow[t]{2}{*}{ UNL } & $1960-1980$ & $5 \%$ & $14 \%$ & $70 \%$ & $11 \%$ & \\
\hline & $1980-2000$ & $8 \%$ & $45 \%$ & $41 \%$ & $6 \%$ & \\
\hline Skilled Labor Intensive & $1960-2000$ & $26 \%$ & $5 \%$ & $60 \%$ & $9 \%$ & 81 \\
\hline \multirow[t]{2}{*}{ SKL } & $1960-1980$ & $30 \%$ & $24 \%$ & $43 \%$ & $3 \%$ & \\
\hline & $1980-2000$ & $13 \%$ & $5 \%$ & $65 \%$ & $16 \%$ & \\
\hline Capital Intensive & $1960-2000$ & $1 \%$ & $49 \%$ & $42 \%$ & $8 \%$ & 79 \\
\hline \multirow[t]{2}{*}{ CAP } & $1960-1980$ & $2 \%$ & $52 \%$ & $43 \%$ & $3 \%$ & \\
\hline & $1980-2000$ & $4 \%$ & $50 \%$ & $41 \%$ & $6 \%$ & \\
\hline Technological Products & $1960-2000$ & $39 \%$ & $25 \%$ & $26 \%$ & $10 \%$ & 67 \\
\hline \multirow[t]{2}{*}{ TEC } & $1960-1980$ & $21 \%$ & $26 \%$ & $46 \%$ & $8 \%$ & \\
\hline & $1980-2000$ & $50 \%$ & $25 \%$ & $15 \%$ & $10 \%$ & \\
\hline
\end{tabular}

*The dependent variable in the ANOVA equations is the predicted probability of being a net exporter of the product.

export land-intensive products and after extracting the capital used in agriculture, their capital abundance ratio is less than that of countries which are relatively less abundant in land. ${ }^{13}$

In the case of the capital stock, here again, we have good results. The positive sign on MIN and NRK (columns 3 and 4) conforms to the characteristics of those sectors. These results contradict those of Leamer (1984), but conform to Estervadeordal's (1997) findings. Endowment of capital reduces the likelihood of being a net exporter of agricultural and processed food commodities. Concerning 
manufactured commodities, there is no evidence yet of a significant impact of capital endowment on labor- and capital-intensive goods. ${ }^{14}$ In this study, by discerning more clusters, we find a negative impact on UNL (column 5) and SKL (column 6) and a positive, but weak, impact on CAP (column 7).

Previous studies did not obtain good results on the human capital component. Estervadeordal (1997) found that skilled labor was significantly positive as was the case with labor-intensive and capital-intensive goods; Lederman and Xu (2001) found that it was significantly negative for all manufactured goods. By distinguishing three sets of skills, we obtain relatively better results, and the results roughly conform to expectations. An increase in the share of non-educated labor or primary educated labor increases the probability of being a net exporter of UNLintensive products. We observe that the increase in this probability is greater for a $1 \%$ increase in the share of primary educated labor $(+0.37 \%)$ than for a $1 \%$ increase in the share of non-educated $(+0.18 \%)$, which means that the UNLintensive sector needs more primary educated labor than non-educated labor.

The coefficients appearing in table 3 are marginal effects calculated for the mean value of the variable. However, we assumed a non-linear relationship, i.e. the impact of an increase in capital per labor differs according to the value of the variable. In the Appendices, we show graphs (Graphs A6.) for several clusters presenting the relationship between the rise in factor endowments and the probability of becoming a net exporter. We can observe that increasing the endowment in a factor has no impact until a sufficient level of the endowment has been reached; in addition, the impact is strong until such a point where additional endowment does not play a role anymore in the probability of becoming net exporter.

We can conclude by the distinction between the two periods (Table A7 in Appendices) that the impact of skills seems more conform to the theory in the second period than in the first one, especially for AGR, PFO, MIN, and NRK sectors. Concerning these sectors, to be well endowed in unskilled labor is a comparative advantage mainly in the second period. We also observe that the impact of land abundance and capital abundance are more conform to the prediction in the second period. However, in the second period, UNL sectors

\footnotetext{
${ }^{13}$ Leamer explains in this why US in 1947 were a net importer of capital intensive goods from Japan whereas US were more capital intensive than Japan.

${ }^{14}$ In Estervadeordal and Leamer, the impact was positive in the two cases, in Lederman and $\mathrm{Xu}$, the impact was negative on labor intensive goods but non significant on capital intensive goods.
} 
seem more sensitive to skilled labor than in the previous period. As expected the endowment in skilled labor is more important in the second period for SKL and TEC sectors. Regarding capital per labor, its impact is more important and conforms to expectations in the second period for all manufactured products (NRK, UNL, CAP and TEC) as well as for MIN sectors, although it ceases to have an impact on primary sectors (AGR and PFO). Finally, results concerning arable land per labor show an increasing and expected impact in the second period for AGR, PFO, and NRK sectors. However, the results on manufactured products are very mixed and do not conform to expectations except for the TEC sector.

\section{(2) The Role of "New" Determinants}

We saw that "new" determinants are determining, especially concerning manufactured products. Among these factors, we assume that because of the presence of "population" which captures scale effects, the log of income per capita captures demand effects. The sign for demand effects should be negative for superior goods. Effectively, increasing income per capita tends to increase the probability of being a net exporter in inferior goods PFO and UNL (column 2 and 5) and a net importer in superior goods CAP or MIN (column 3 and 7). The scale effects should be positive for products with increasing returns to scale, in industry and especially high technology industry. The results tend to confirm that prediction since the size of the population is significantly positive for all industrial products (UNL, SKL, CAP and TEC). The measure of factor productivity seems to be more important in the second period (Table A5. in Appendices), and leads countries to be net exporters of manufactured goods or PFO (column 2).

\section{(3) Infrastructure and ICT}

Generally, an improvement in infrastructure and ICT leads countries to be net exporters of manufactured products and net importers of primary products. Results confirm that theory for infrastructure, whereas results for ICT and not significant. They not very important in our model, however, so we could assume that they mainly play a role in trade intensity, but are not very determining in terms of trade structure. Nevertheless, the distinction in two periods (Table A6. in Appendices) shows us that ICT and infrastructure improvements tend to increase the chance for a country to develop a 
Table 3. Determinants of Comparative Advantage: Heckman Selection Equation: Probit on the Probability of Being a Net Exporter of Each Commodity Cluster on 1960-2000.

\begin{tabular}{|c|c|c|c|c|c|c|c|c|}
\hline & 1 & 2 & 3 & 4 & 5 & 6 & 7 & 8 \\
\hline $\begin{array}{l}\text { Probability of Being } \\
\text { a Net Exporter }\end{array}$ & AGR & PFO & MIN & NRK & UNL & SKL & CAP & TEC \\
\hline Capital & $\begin{array}{r}-\mathbf{- 0 . 1 4 5}^{\mathrm{b}} \\
(2.10)\end{array}$ & $\begin{array}{l}-\mathbf{0 . 2 0 7 ^ { \mathrm { a } }} \\
(3.05)\end{array}$ & $\begin{array}{l}\mathbf{0 . 3 6 7}^{\mathrm{a}} \\
(4.58)\end{array}$ & $\begin{array}{r}\mathbf{0 . 2 9 9}^{\mathrm{a}} \\
(4.09)\end{array}$ & $\begin{array}{r}-\mathbf{- 0 . 3 4 3}^{\mathrm{a}} \\
(4.89)\end{array}$ & $\begin{array}{r}-\mathbf{- 0 . 1 0 1}^{\mathrm{b}} \\
(2.07)\end{array}$ & $\begin{array}{l}\mathbf{0 . 0 0 3}^{\mathrm{c}} \\
(1.85)\end{array}$ & $\begin{array}{l}0.0001 \\
(0.90)\end{array}$ \\
\hline Land & $\begin{array}{l}\mathbf{0 . 1 5 7}^{\mathrm{a}} \\
(4.74)\end{array}$ & $\begin{array}{l}\mathbf{0 . 3 0 8}^{\mathrm{a}} \\
(7.57)\end{array}$ & $\begin{array}{r}-0.048^{\mathrm{c}} \\
(1.68)\end{array}$ & $\begin{array}{l}\mathbf{0 . 2 8 0}^{\mathrm{a}} \\
(7.39)\end{array}$ & $\begin{array}{l}0.068^{\mathrm{b}} \\
(2.46)\end{array}$ & $\begin{array}{r}\mathbf{- 0 . 0 5 2}^{\mathrm{a}} \\
(3.71)\end{array}$ & $\begin{array}{l}0.001 \\
(1.59)\end{array}$ & $\begin{array}{c}\mathbf{- 0 . 0 0 0 1}^{\mathrm{a}} \\
(3.88)\end{array}$ \\
\hline Unskilled & $\begin{array}{l}-0.054 \\
(1.47)\end{array}$ & $\begin{array}{l}\mathbf{0 . 1 0 7}^{\mathrm{a}} \\
(2.76)\end{array}$ & $\begin{array}{l}\mathbf{0 . 0 8 6}^{\mathrm{b}} \\
(2.32)\end{array}$ & $\begin{array}{l}\mathbf{0 . 1 6 4}^{\mathrm{a}} \\
(4.26)\end{array}$ & $\begin{array}{l}\mathbf{0 . 1 8 0}^{\mathrm{a}} \\
(4.10)\end{array}$ & $\begin{array}{r}-0.004 \\
(0.28)\end{array}$ & $\begin{array}{r}\mathbf{- 0 . 0 0 2}^{\mathrm{b}} \\
(2.51)\end{array}$ & $\begin{array}{c}-0.0000 \\
(1.03)\end{array}$ \\
\hline Primary & $\begin{array}{r}-0.116^{\mathrm{b}} \\
(2.01)\end{array}$ & $\begin{array}{l}\mathbf{0 . 1 5 8}^{\mathrm{b}} \\
(2.37)\end{array}$ & $\begin{array}{r}-0.170^{\mathrm{a}} \\
(2.90)\end{array}$ & $\begin{array}{l}\mathbf{0 . 2 2 2}^{\mathrm{a}} \\
(3.47)\end{array}$ & $\begin{array}{l}\mathbf{0 . 3 7 1}^{\mathrm{a}} \\
(5.36)\end{array}$ & $\begin{array}{l}0.111^{\mathrm{a}} \\
(3.78)\end{array}$ & $\begin{array}{l}0.005^{\mathrm{a}} \\
(2.97)\end{array}$ & $\begin{array}{c}0.0001^{\mathrm{c}} \\
(1.91)\end{array}$ \\
\hline High-Secondary & $\begin{array}{l}-0.035 \\
(0.58)\end{array}$ & $\begin{array}{l}-0.015 \\
(0.25)\end{array}$ & $\begin{array}{l}0.247^{\mathrm{a}} \\
(4.18)\end{array}$ & $\begin{array}{l}0.262^{\mathrm{a}} \\
(4.40)\end{array}$ & $\begin{array}{l}0.080 \\
(1.18)\end{array}$ & $\begin{array}{l}0.090^{\mathrm{a}} \\
(2.84)\end{array}$ & $\begin{array}{l}0.001 \\
(0.56)\end{array}$ & $\begin{array}{l}0.0001 \\
(0.73)\end{array}$ \\
\hline Income p.c. & $\begin{array}{l}0.058 \\
(0.50)\end{array}$ & $\begin{array}{l}\mathbf{0 . 2 8 1}^{\mathrm{a}} \\
(2.59)\end{array}$ & $\begin{array}{r}-0.222^{\mathrm{c}} \\
(1.80)\end{array}$ & $\begin{array}{c}-0.143 \\
(1.26)\end{array}$ & $\begin{array}{l}\mathbf{0 . 3 1 0}^{\mathrm{a}} \\
(2.77)\end{array}$ & $\begin{array}{l}0.061 \\
(0.82)\end{array}$ & $\begin{array}{r}\mathbf{- 0 . 0 0 4}^{\mathrm{c}} \\
(1.66)\end{array}$ & $\begin{array}{c}-0.0002 \\
(1.43)\end{array}$ \\
\hline Population & $\begin{array}{r}-\mathbf{- 0 . 0 4 5}^{\mathrm{b}} \\
(2.15)\end{array}$ & $\begin{array}{l}-0.022 \\
(0.97)\end{array}$ & $\begin{array}{l}0.037^{\mathrm{c}} \\
(1.73)\end{array}$ & $\begin{array}{l}-0.016 \\
(0.72)\end{array}$ & $\begin{array}{l}\mathbf{0 . 1 7 2}^{\mathrm{a}} \\
(7.65)\end{array}$ & $\begin{array}{l}\mathbf{0 . 0 6 1}^{\mathrm{a}} \\
(5.86)\end{array}$ & $\begin{array}{r}\mathbf{0 . 0 0 3}^{\mathrm{a}} \\
(5.74)\end{array}$ & $\begin{array}{c}\mathbf{0 . 0 0 0 1}^{\mathrm{a}} \\
(5.54)\end{array}$ \\
\hline TFP & $\begin{array}{l}0.031 \\
(0.22)\end{array}$ & $\begin{array}{l}0.357^{\mathrm{a}} \\
(2.65)\end{array}$ & $\begin{array}{r}-0.223^{\mathrm{c}} \\
(1.71)\end{array}$ & $\begin{array}{l}0.045 \\
(0.35)\end{array}$ & $\begin{array}{l}\mathbf{0 . 4 6 6}^{\mathrm{a}} \\
(3.75)\end{array}$ & $\begin{array}{l}\mathbf{0 . 1 4 0}^{\mathrm{b}} \\
(2.03)\end{array}$ & $\begin{array}{l}\mathbf{0 . 0 0 9}^{\mathrm{a}} \\
(3.10)\end{array}$ & $\begin{array}{c}-0.0000 \\
(0.38)\end{array}$ \\
\hline ICT & $\begin{array}{l}0.006 \\
(0.27)\end{array}$ & $\begin{array}{l}-\mathbf{0 . 0 4 7} 7^{\mathrm{b}} \\
(2.09)\end{array}$ & $\begin{array}{l}-0.007 \\
(0.33)\end{array}$ & $\begin{array}{l}0.028 \\
(1.38)\end{array}$ & $\begin{array}{r}-0.075^{\mathrm{a}} \\
(3.68)\end{array}$ & $\begin{array}{l}-0.002 \\
(0.22)\end{array}$ & $\begin{array}{l}-0.000 \\
(0.40)\end{array}$ & $\begin{array}{r}\mathbf{0 . 0 0 0 0}^{\mathrm{c}} \\
(1.84)\end{array}$ \\
\hline Infrastructure & $\begin{array}{c}-0.002 \\
(0.02)\end{array}$ & $\begin{array}{l}0.132^{\mathrm{c}} \\
(1.81)\end{array}$ & $\begin{array}{c}-\mathbf{- 0 . 2 0 6}^{\mathrm{a}} \\
(2.77)\end{array}$ & $\begin{array}{r}-\mathbf{- 0 . 1 2 0}{ }^{c} \\
(1.71)\end{array}$ & $\begin{array}{r}\mathbf{0 . 3 2 2}^{\mathrm{a}} \\
(4.41)\end{array}$ & $\begin{array}{l}0.051 \\
(1.32)\end{array}$ & $\begin{array}{l}\mathbf{0 . 0 0 4}^{\mathrm{b}} \\
(2.10)\end{array}$ & $\begin{array}{c}\mathbf{0 . 0 0 0 2}^{\mathrm{b}} \\
(2.31)\end{array}$ \\
\hline $\begin{array}{c}\text { Regional Dummies } \\
\text { Observations }\end{array}$ & $\begin{array}{l}\text { Yes } \\
461\end{array}$ & $\begin{array}{l}\text { Yes } \\
461\end{array}$ & $\begin{array}{l}\text { Yes } \\
443\end{array}$ & $\begin{array}{l}\text { Yes } \\
465\end{array}$ & $\begin{array}{l}\text { Yes } \\
461\end{array}$ & $\begin{array}{l}\text { Yes } \\
462\end{array}$ & $\begin{array}{l}\text { Yes } \\
456\end{array}$ & $\begin{array}{l}\text { Yes } \\
454\end{array}$ \\
\hline
\end{tabular}

The coefficients are marginal coefficients.

a: means significant at $1 \%$, b: means significant at $5 \%$ and $\mathrm{c}$ : means significant at $10 \%$ 
comparative advantage in manufacture industry. An interesting result is that a one percent increase in the infrastructure index increases the probability of being net exporter of UNL by 0.32 , which is almost as important as a one percent increase in primary educated labor.

\section{Intensity of Trade}

Among the structural variables, the size of the country, measured by population, presents strongly significant results in reducing net exports for net exporters (table 4) and net imports for net importers (table 5). Here, population does not capture scale effects but only the country's size. In fact, having a large domestic market size reduces trade flows. The results concerning the impact of income per capita on consumer preferences are not clear although it is generally expected that consumers prefer higher quality goods as their income increases. It seems that, like population, income per capita captures a market size effect which decreases both net exports for net exporters and net imports for net importers. In the previous section, we have shown that differences in technology could explain trade specialization; as noted earlier differences in productivity might affect trade patterns by affecting trade intensity since an improvement in the productivity leads net exporting as well as net importing countries, to increase their net exports in manufactured products. Trade flows are significantly determined by transport costs (infrastructure) and seem less sensitive to transaction cost (ICT). Infrastructure is really important determinants for capital and technology intensive product.

Concerning the trade policy measure, the results are interesting. The trade policy variable increases net exports for net exporters and net imports for net importers. The results are quite different among clusters. For net exporters, the results suggest that protection favors skilled and unskilled intensive goods and agricultural goods, possibly at the expense of most sophisticated manufactured goods. It seems that for net importers (Table 5), protection tends to favor capital-intensive and technological-intensive products, but also agricultural and processed food goods. The coefficients in table 4 and 5 indicate that even if trade liberalization stimulated export growth, it raised import growth by more, as in Santos Paulino and Thirwall (2004).

The Mills' inverse ratio, which estimates the correlation between the error from comparative advantage equation and the error from trade intensity equations, is sometimes significant. This suggests that part of trade intensity not explained by 
Table 4. Trade Intensity: Heckman's Second Equation: OLS on Net Exports for Net Exporters

\begin{tabular}{|c|c|c|c|c|c|c|c|c|}
\hline & 1 & 2 & 3 & 4 & 5 & 6 & 7 & 8 \\
\hline $\operatorname{Ln}\left(c+\frac{X-M}{P I B}\right)$ & AGR & PFO & MIN & NRK & UNL & SKL & CAP & TEC \\
\hline Income p.c. & $\begin{array}{l}-0.054 \\
(1.50)\end{array}$ & $\begin{array}{c}\mathbf{- 0 . 0 7 3}^{\mathrm{a}} \\
(2.62)\end{array}$ & $\begin{array}{l}0.054^{\mathrm{b}} \\
(2.47)\end{array}$ & $\begin{array}{c}-\mathbf{0 . 2 1 4}{ }^{\mathrm{a}} \\
(2.75)\end{array}$ & $\begin{array}{c}\mathbf{- 0 . 1 5 5}^{\mathrm{a}} \\
(4.01)\end{array}$ & $\begin{array}{c}-0.001 \\
(0.09)\end{array}$ & $\begin{array}{c}\mathbf{- 0 . 1 3 1}^{\mathrm{a}} \\
(2.94)\end{array}$ & $\begin{array}{r}-\mathbf{0 . 1 6 0}{ }^{c} \\
(1.83)\end{array}$ \\
\hline Population & $\begin{array}{r}\mathbf{- 0 . 0 5 4} 4^{\mathrm{a}} \\
(7.04)\end{array}$ & $\begin{array}{c}\mathbf{- 0 . 0 4 4}^{\mathrm{a}} \\
(5.32)\end{array}$ & $\begin{array}{c}-\mathbf{- 0 . 0 1 3}^{\mathrm{a}} \\
(4.01)\end{array}$ & $\begin{array}{r}\mathbf{- 0 . 0 7 3}^{\mathrm{a}} \\
(4.03)\end{array}$ & $\begin{array}{c}\mathbf{- 0 . 0 2 5}^{\mathrm{b}} \\
(2.53)\end{array}$ & $\begin{array}{c}-0.006 \\
(1.48)\end{array}$ & $\begin{array}{c}\mathbf{- 0 . 0 4 5}^{\mathrm{a}} \\
(5.07)\end{array}$ & $\begin{array}{l}-0.014 \\
(0.62)\end{array}$ \\
\hline TFP & $\begin{array}{l}0.011 \\
(0.80)\end{array}$ & $\begin{array}{l}-0.012 \\
(1.59)\end{array}$ & $\begin{array}{l}0.007 \\
(1.06)\end{array}$ & $\begin{array}{l}0.057^{\mathrm{a}} \\
(2.93)\end{array}$ & $\begin{array}{l}0.004 \\
(0.51)\end{array}$ & $\begin{array}{c}-0.004 \\
(1.40)\end{array}$ & $\begin{array}{l}0.004 \\
(0.61)\end{array}$ & $\begin{array}{l}0.007 \\
(0.70)\end{array}$ \\
\hline Partner Growth & $\begin{array}{l}0.087 \\
(0.67)\end{array}$ & $\begin{array}{l}0.256^{\mathrm{a}} \\
(2.87)\end{array}$ & $\begin{array}{c}-0.288^{\mathrm{a}} \\
(3.03)\end{array}$ & $\begin{array}{l}0.258 \\
(1.17)\end{array}$ & $\begin{array}{l}-0.090 \\
(0.87)\end{array}$ & $\begin{array}{l}0.010 \\
(0.25)\end{array}$ & $\begin{array}{r}-0.077 \\
(0.76)\end{array}$ & $\begin{array}{l}0.317^{\mathrm{c}} \\
(1.72)\end{array}$ \\
\hline Landlockness & $\begin{array}{c}-\mathbf{0 . 1 7 9} \\
(4.30)\end{array}$ & $\begin{array}{l}0.025 \\
(0.58)\end{array}$ & $\begin{array}{l}0.167^{\mathrm{b}} \\
(2.43)\end{array}$ & $\begin{array}{l}0.131^{\mathrm{b}} \\
(2.23)\end{array}$ & $\begin{array}{c}\mathbf{- 0 . 0 9 5}^{\mathrm{a}} \\
(3.45)\end{array}$ & $\begin{array}{l}-0.012 \\
(1.02)\end{array}$ & $\begin{array}{c}\mathbf{- 0 . 2 2 3}^{\mathrm{a}} \\
(7.32)\end{array}$ & $\begin{array}{l}0.180^{\mathrm{a}} \\
(2.71)\end{array}$ \\
\hline Infrastructure & $\begin{array}{l}-0.035 \\
(1.16)\end{array}$ & $\begin{array}{l}\mathbf{0 . 0 7 0}^{\mathrm{a}} \\
(3.34)\end{array}$ & $\begin{array}{c}-0.052^{\mathrm{a}} \\
(3.53)\end{array}$ & $\begin{array}{l}0.072 \\
(1.50)\end{array}$ & $\begin{array}{l}\mathbf{0 . 0 6 0 ^ { b }} \\
(2.45)\end{array}$ & $\begin{array}{l}-0.011 \\
(0.91)\end{array}$ & $\begin{array}{l}\mathbf{0 . 1 5 4}{ }^{\mathrm{a}} \\
(3.65)\end{array}$ & $\begin{array}{l}\mathbf{0 . 2 8 1}^{\mathrm{a}} \\
(2.79)\end{array}$ \\
\hline ICT & $\begin{array}{l}-0.006 \\
(0.82)\end{array}$ & $\begin{array}{l}-0.010 \\
(1.44)\end{array}$ & $\begin{array}{l}-0.003 \\
(0.85)\end{array}$ & $\begin{array}{l}0.011 \\
(1.15)\end{array}$ & $\begin{array}{l}\mathbf{0 . 0 2 4}^{\mathrm{a}} \\
(2.64)\end{array}$ & $\begin{array}{c}\mathbf{0 . 0 0 8}^{\mathrm{c}} \\
(1.82)\end{array}$ & $\begin{array}{l}0.001 \\
(0.21)\end{array}$ & $\begin{array}{l}0.012 \\
(1.26)\end{array}$ \\
\hline Index WW & $\begin{array}{l}\mathbf{0 . 0 3 4}^{\mathrm{c}} \\
(1.90)\end{array}$ & $\begin{array}{l}0.001 \\
(0.02)\end{array}$ & $\begin{array}{l}\mathbf{0 . 0 4 4}{ }^{b} \\
(2.19)\end{array}$ & $\begin{array}{l}-0.078 \\
(1.25)\end{array}$ & $\begin{array}{l}\mathbf{0 . 0 5 2}^{b} \\
(2.42)\end{array}$ & $\begin{array}{l}\mathbf{0 . 0 1 7}^{\mathrm{c}} \\
(1.87)\end{array}$ & $\begin{array}{c}-0.022 \\
(0.62)\end{array}$ & $\begin{array}{l}-0.110 \\
(1.45)\end{array}$ \\
\hline Mills Ratio & $\begin{array}{c}-0.083^{\mathrm{a}} \\
(2.71)\end{array}$ & $\begin{array}{c}-0.037^{\mathrm{c}} \\
(1.80)\end{array}$ & $\begin{array}{c}-0.031^{\mathrm{c}} \\
(1.71)\end{array}$ & $\begin{array}{c}-0.309^{\mathrm{a}} \\
(3.50)\end{array}$ & $\begin{array}{c}-0.046^{\mathrm{b}} \\
(2.49)\end{array}$ & $\begin{array}{c}-0.003 \\
(0.19)\end{array}$ & $\begin{array}{l}0.076^{\mathrm{a}} \\
(3.17)\end{array}$ & $\begin{array}{l}0.121 \\
(1.29)\end{array}$ \\
\hline Constant & $\begin{array}{l}8.321^{\mathrm{a}} \\
(19.21)\end{array}$ & $\begin{array}{l}7.740^{\mathrm{a}} \\
(24.77)\end{array}$ & $\begin{array}{c}7.509^{\mathrm{a}} \\
(30.21)\end{array}$ & $\begin{array}{l}9.786^{\mathrm{a}} \\
(11.84)\end{array}$ & $\begin{array}{c}9.004^{\mathrm{a}} \\
(16.74)\end{array}$ & $\begin{array}{c}7.038^{\mathrm{a}} \\
(49.74)\end{array}$ & $\begin{array}{c}8.987^{a} \\
(16.29)\end{array}$ & $\begin{array}{l}7.510^{\mathrm{a}} \\
(9.49)\end{array}$ \\
\hline Observations & 262 & 234 & 199 & 180 & 151 & 89 & 78 & 62 \\
\hline R-squared & 0.34 & 0.25 & 0.31 & 0.42 & 0.23 & 0.17 & 0.51 & 0.43 \\
\hline
\end{tabular}

a: means significant at $1 \%$, b: means significant at $5 \%$ and c: means significant at $10 \%$

the explanatory variables is significantly correlated with unexplained comparative advantage, and that explanatory variables in the second step (trade intensity) are correlated with unobserved variables in the first step (comparative advantage). So, by correcting for that correlation, we have avoided a bias in the estimation of parameters in the second step.

\section{Conclusions}

Using a non-linear estimation, we have attempted to improve the commodity version of the H-O model by adding "new" determinants - trade impediments, and differences in technology, consumers' preferences, and returns to scale - developed 
Table 5. Trade Intensity: Heckman's Second Equation: OLS on Net Imports for Net Importers

\begin{tabular}{|c|c|c|c|c|c|c|c|c|}
\hline & 1 & 2 & 3 & 4 & 5 & 6 & 7 & 8 \\
\hline $\operatorname{Ln}\left(c+\frac{X-M}{P I B}\right)$ & AGR & PFO & MIN & NRK & UNL & SKL & CAP & TEC \\
\hline Income p.c. & $\begin{array}{c}\mathbf{0 . 0 5 4}^{\mathrm{a}} \\
(3.21)\end{array}$ & $\begin{array}{l}0.007 \\
(0.44)\end{array}$ & $\begin{array}{l}0.006 \\
(1.51)\end{array}$ & $\begin{array}{l}-0.000 \\
(0.07)\end{array}$ & $\begin{array}{c}\mathbf{0 . 0 3 0}^{\mathrm{b}} \\
(2.36)\end{array}$ & $\begin{array}{l}\mathbf{0 . 0 3 2}^{\mathrm{a}} \\
(5.97)\end{array}$ & $\begin{array}{c}\mathbf{0 . 0 7 6}^{\mathrm{a}} \\
(4.87)\end{array}$ & $\begin{array}{l}\mathbf{0 . 1 1 1}^{\mathrm{a}} \\
(5.07)\end{array}$ \\
\hline Population & $\begin{array}{l}\mathbf{0 . 0 1 3}^{\text {a }} \\
(4.47)\end{array}$ & $\begin{array}{c}\mathbf{0 . 0 1 6}^{\mathrm{a}} \\
(4.86)\end{array}$ & $\begin{array}{c}\mathbf{- 0 . 0 0 2}^{\mathrm{b}} \\
(2.43)\end{array}$ & $\begin{array}{c}\mathbf{0 . 0 0 5}^{\mathrm{a}} \\
(5.83)\end{array}$ & $\begin{array}{c}\mathbf{0 . 0 2 0}^{\mathrm{a}} \\
(6.44)\end{array}$ & $\begin{array}{c}\mathbf{0 . 0 1 7}^{\mathrm{a}} \\
(10.34)\end{array}$ & $\begin{array}{c}\mathbf{0 . 0 4 8}^{\mathrm{a}} \\
(12.81)\end{array}$ & $\begin{array}{l}\mathbf{0 . 0 4 3}^{\text {a }} \\
(9.17)\end{array}$ \\
\hline TFP & $\begin{array}{c}-0.005 \\
(1.14)\end{array}$ & $\begin{array}{l}0.012^{\mathrm{a}} \\
(4.06)\end{array}$ & $\begin{array}{c}-0.004^{\mathrm{a}} \\
(2.61)\end{array}$ & $\begin{array}{l}0.003^{\mathrm{a}} \\
(3.04)\end{array}$ & $\begin{array}{l}0.002 \\
(0.64)\end{array}$ & $\begin{array}{l}0.001 \\
(0.81)\end{array}$ & $\begin{array}{l}0.009^{c} \\
(1.94)\end{array}$ & $\begin{array}{l}0.007 \\
(1.46)\end{array}$ \\
\hline Partner Growth & $\begin{array}{l}0.068 \\
(1.13)\end{array}$ & $\begin{array}{l}0.026 \\
(0.55)\end{array}$ & $\begin{array}{l}0.010 \\
(0.54)\end{array}$ & $\begin{array}{l}0.006 \\
(0.41)\end{array}$ & $\begin{array}{c}-0.149^{\mathrm{a}} \\
(3.31)\end{array}$ & $\begin{array}{l}0.009 \\
(0.51)\end{array}$ & $\begin{array}{l}-0.036 \\
(0.55)\end{array}$ & $\begin{array}{l}0.060 \\
(0.85)\end{array}$ \\
\hline Landlockness & $\begin{array}{l}\mathbf{0 . 0 3 4}^{\mathrm{b}} \\
(2.28)\end{array}$ & $\begin{array}{c}\mathbf{0 . 0 2 1}^{\mathrm{b}} \\
(2.05)\end{array}$ & $\begin{array}{c}-0.001 \\
(0.17)\end{array}$ & $\begin{array}{c}-0.001 \\
(0.12)\end{array}$ & $\begin{array}{c}\mathbf{0 . 0 2 6}^{\mathrm{a}} \\
(3.53)\end{array}$ & $\begin{array}{l}\mathbf{0 . 0 1 1}^{\mathrm{c}} \\
(1.72)\end{array}$ & $\begin{array}{c}\mathbf{0 . 0 2 8}^{\mathrm{c}} \\
(1.83)\end{array}$ & $\begin{array}{l}0.034 \\
(1.32)\end{array}$ \\
\hline Infrastructure & $\begin{array}{r}-0.010 \\
(0.90)\end{array}$ & $\begin{array}{l}0.008 \\
(0.73)\end{array}$ & $\begin{array}{c}-\mathbf{- 0 . 0 1 0}^{\mathrm{a}} \\
(3.26)\end{array}$ & $\begin{array}{c}0.001 \\
(0.29)\end{array}$ & $\begin{array}{r}\mathbf{- 0 . 0 1 6}^{\mathrm{C}} \\
(1.71)\end{array}$ & $\begin{array}{c}\mathbf{- 0 . 0 1 1}^{\mathrm{a}} \\
(2.81)\end{array}$ & $\begin{array}{c}\mathbf{- 0 . 0 2 9}^{\mathrm{b}} \\
(2.34)\end{array}$ & $\begin{array}{c}\mathbf{- 0 . 0 4 3}^{\mathrm{a}} \\
(2.72)\end{array}$ \\
\hline ICT & $\begin{array}{c}0.005^{\mathrm{b}} \\
(1.98)\end{array}$ & $\begin{array}{l}0.002 \\
(0.60)\end{array}$ & $\begin{array}{l}0.003^{\mathrm{b}} \\
(2.40)\end{array}$ & $\begin{array}{l}0.000 \\
(0.28)\end{array}$ & $\begin{array}{c}-0.000 \\
(0.25)\end{array}$ & $\begin{array}{c}\mathbf{- 0 . 0 0 7}^{\mathrm{a}} \\
(4.50)\end{array}$ & $\begin{array}{l}0.001 \\
(0.10)\end{array}$ & $\begin{array}{c}-0.007 \\
(1.05)\end{array}$ \\
\hline Index WW & $\begin{array}{c}\mathbf{- 0 . 0 2 4}^{\mathrm{c}} \\
(1.93)\end{array}$ & $\begin{array}{c}\mathbf{- 0 . 0 3 3}^{\text {b }} \\
(2.52)\end{array}$ & $\begin{array}{c}\mathbf{- 0 . 0 0 6}^{\mathrm{c}} \\
(1.86)\end{array}$ & $\begin{array}{c}-\mathbf{- 0 . 0 0 9}^{\mathrm{b}} \\
(2.58)\end{array}$ & $\begin{array}{c}-0.002 \\
(0.25)\end{array}$ & $\begin{array}{c}\mathbf{- 0 . 0 1 0}^{\mathrm{b}} \\
(2.48)\end{array}$ & $\begin{array}{c}-\mathbf{- 0 . 0 8 2}^{\mathrm{a}} \\
(5.93)\end{array}$ & $\begin{array}{c}\mathbf{- 0 . 0 5 6}^{\mathrm{a}} \\
(3.54)\end{array}$ \\
\hline Mills Ratio & $\begin{array}{l}0.043^{\mathrm{a}} \\
(4.49)\end{array}$ & $\begin{array}{l}0.065^{\mathrm{a}} \\
(5.52)\end{array}$ & $\begin{array}{l}-0.008 \\
(1.50)\end{array}$ & $\begin{array}{l}0.010^{\mathrm{a}} \\
(3.42)\end{array}$ & $\begin{array}{l}0.028^{\mathrm{a}} \\
(3.75)\end{array}$ & $\begin{array}{l}0.004 \\
(0.37)\end{array}$ & $\begin{array}{l}0.086^{\mathrm{a}} \\
(3.39)\end{array}$ & $\begin{array}{l}0.154^{\mathrm{a}} \\
(4.79)\end{array}$ \\
\hline Constant & $\begin{array}{c}5.966^{\mathrm{a}} \\
(27.11)\end{array}$ & $\begin{array}{c}6.467^{\mathrm{a}} \\
(50.26)\end{array}$ & $\begin{array}{c}6.869^{\mathrm{a}} \\
(138.19)\end{array}$ & $\begin{array}{c}6.817^{\mathrm{a}} \\
(177.41)\end{array}$ & $\begin{array}{c}6.666^{\mathrm{a}} \\
(74.92)\end{array}$ & $\begin{array}{c}6.330^{\mathrm{a}} \\
(117.89)\end{array}$ & $\begin{array}{c}5.446^{\mathrm{a}} \\
(28.88)\end{array}$ & $\begin{array}{l}4.909^{\mathrm{a}} \\
(20.26)\end{array}$ \\
\hline Observations & 196 & 226 & 240 & 281 & 306 & 369 & 374 & 388 \\
\hline R-squared & 0.31 & 0.35 & 0.20 & 0.24 & 0.34 & 0.47 & 0.45 & 0.35 \\
\hline
\end{tabular}

a: means significant at $1 \%$, b: means significant at $5 \%$ and c: means significant at $10 \%$

in the factor content literature as well as determinants of trade structure and trade intensity. Compared to the previous studies, our analysis employed a more detailed cluster classification, leading to more clusters for manufactured products. The following eight clusters were used: agriculture (AGR), processed food (PFO), minerals (MIN), natural resources based- manufactures (NRK), unskilled laborintensive (UNL), skilled labor-intensive (SKL), capital-intensive (CAP) and technology-intensive (TEC). Furthermore, to ensure a better assessment of the specialization according to human capital, we distinguished among three sets of skills: unskilled, primary skilled, and highly skilled.

We implemented the Heckman procedure, where in the first step we estimated the probability of being a net exporter for each eight product clusters (what we call the comparative advantage equation). As explanatory variables in this step, we 
included factor endowments and the new determinants which may affect specialization. In the second step, on the other hand, we estimated the trade intensity of net exports for each cluster, depending on new determinants as well as on trade policy. This procedure helped us control for the correlation between the unobserved variables which explain trade specialization and the explanatory variables of trade intensity.

Our major findings are as follows. First, we find that conventional factors are still important in determining trade structure, arguably because we have a better measure of factor endowment (e.g the factor endowment of a country is weighted by the mean factor endowment of the world) and a better cluster classification. Second, we find that new determinants (e.g. difference in productivity, consumers' preferences, and scale returns) need to be included to determine comparative advantage, especially for the manufactured products. Controlling for factor endowments, a better technology or scale economies enhance comparative advantage for manufactured products. Moreover, an increase in mean income leads consumers to prefer high-quality goods (capitalintensive products or mineral-intensive products) relative to low-quality goods (low skilled labor-intensive products and processed food), which changes the net exports structure. An improvement in information and communication technology or infrastructure also helps a country to reduce dependence on primary products.

Furthermore, turning to the change across periods, the results indicate that differences in factor endowments have not diminished over time: we observe an increase in specialization according to skill endowment. Hence, differences in productivity, in returns to scale or in consumers' preferences are not new forces that drive trade flows, they were also important before 1980. This is an important conclusion since no study has investigated this aspect before.

Estimation of trade intensity also yields plausible results. First, country size matters as expected, as trade intensity decreases with population. Second, a reduction in our proxy for trade barriers, increases trade intensity for both net exporter and for net importer clusters. However, its effects are not uniform among sectors. Third, a reduction in barriers to trade increases trade intensity, with a stronger effect for infrastructure-related costs than for transaction-related costs. Finally, for manufactured clusters, increases in TFP raises net exports and reduces net imports for manufactured products. As for the overall two-step procedure, the statistical test (Mills ratio) accepts the two-step procedure. 
In sum, the specialization according to factor endowments is always relevant, although "new" determinants of trade patterns are necessary to explain specialization and trade intensity.

\section{Acknowledgements}

The author thanks Jaime de Melo, Marcelo Olarreaga and Lionel Fontagne for helpful comments on earlier drafts.

Received 11 June 2007, Revised 22 September 2008, Accepted 7 October 2008 


\section{Appendices}

A1. List of Countries Included in the Sample 1970-2000

\begin{tabular}{|c|c|c|}
\hline & Countries & observations \\
\hline \multirow{20}{*}{ 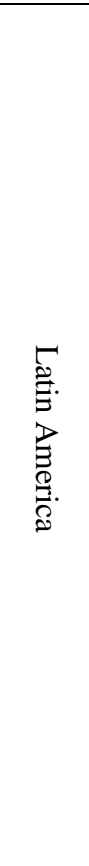 } & Argentina & 8 \\
\hline & Bolivia & 8 \\
\hline & Brazil & 8 \\
\hline & Chile & 8 \\
\hline & Colombia & 8 \\
\hline & Costa Rica & 7 \\
\hline & Dominican Republic & 5 \\
\hline & Ecuador & 8 \\
\hline & El Salvador & 8 \\
\hline & Guatemala & 7 \\
\hline & Honduras & 8 \\
\hline & Jamaica & 7 \\
\hline & Mexico & 8 \\
\hline & Nicaragua & 7 \\
\hline & Panama & 8 \\
\hline & Paraguay & 8 \\
\hline & Peru & 8 \\
\hline & Trinidad and Tobago & 6 \\
\hline & Uruguay & 6 \\
\hline & Venezuela, RB & 8 \\
\hline Total & 20 & 149 \\
\hline \multirow{17}{*}{ 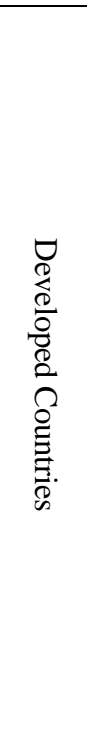 } & Australia & 7 \\
\hline & Austria & 7 \\
\hline & Belgium & 1 \\
\hline & Canada & 7 \\
\hline & Cyprus & 5 \\
\hline & Denmark & 6 \\
\hline & Finland & 7 \\
\hline & France & 8 \\
\hline & Greece & 8 \\
\hline & Ireland & 8 \\
\hline & Italy & 8 \\
\hline & Japan & 8 \\
\hline & Netherlands & 7 \\
\hline & New Zealand & 5 \\
\hline & Norway & 7 \\
\hline & Portugal & 8 \\
\hline & Spain & 8 \\
\hline
\end{tabular}

\begin{tabular}{|c|c|c|}
\hline & Sweden & 8 \\
\hline & Switzerland & 8 \\
\hline & United Kingdom & 8 \\
\hline & United States & 8 \\
\hline Total & 21 & 147 \\
\hline \multirow{20}{*}{ 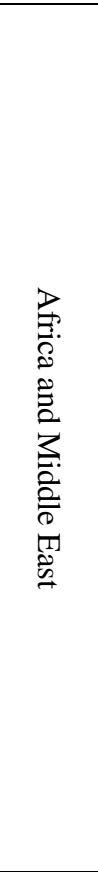 } & Countries & observations \\
\hline & Algeria & 6 \\
\hline & Egypt, Arab Rep. & 5 \\
\hline & Ghana & 7 \\
\hline & Iran, Islamic Rep. & 3 \\
\hline & Israel & 8 \\
\hline & Jordan & 7 \\
\hline & Kenya & 5 \\
\hline & Mali & 7 \\
\hline & Mauritius & 6 \\
\hline & Rwanda & 1 \\
\hline & Senegal & 8 \\
\hline & Sierra Leone & 4 \\
\hline & South Africa & 4 \\
\hline & Tanzania & 2 \\
\hline & Tunisia & 8 \\
\hline & Turkey & 7 \\
\hline & Uganda & 2 \\
\hline & Zambia & 4 \\
\hline & Zimbabwe & 4 \\
\hline Total & 19 & 98 \\
\hline \multirow{11}{*}{$\frac{D}{\Delta}}$. & Bangladesh & 5 \\
\hline & China & 4 \\
\hline & India & 8 \\
\hline & Indonesia & 7 \\
\hline & Korea, Rep. & 8 \\
\hline & Malaysia & 7 \\
\hline & Pakistan & 6 \\
\hline & Philippines & 8 \\
\hline & Singapore & 8 \\
\hline & Sri Lanka & 8 \\
\hline & Thailand & 8 \\
\hline Total & 11 & 77 \\
\hline
\end{tabular}


A2. Construction of Clusters

\begin{tabular}{|c|c|c|c|c|c|c|c|}
\hline NAPES & Sitc Rev.2 & Leamer & Sitc Rev.2 & Marrewjick & Sitc Rev.2 & Gourdon & Sitc Rev.2 \\
\hline Agriculture & $\begin{array}{l}00,041- \\
045,051, \\
052,054, \\
2-27-28\end{array}$ & \multirow{2}{*}{$\begin{array}{c}\text { Forest, } \\
\text { Tropical, } \\
\text { Cereals } \\
\text { Animal } \\
\text { Products }\end{array}$} & \multirow[b]{2}{*}{$\begin{array}{l}0,1,2-27- \\
28,63,64\end{array}$} & \multirow{3}{*}{ Primary } & \multirow{3}{*}{$\begin{array}{l}0,1,2, \\
3,4\end{array}$} & $\begin{array}{l}\text { Agriculture } \\
\text { (AGR) }\end{array}$ & $\begin{array}{l}00,041- \\
045,051 \\
052,054 \\
2-27-28\end{array}$ \\
\hline $\begin{array}{l}\text { Processed } \\
\text { Food }\end{array}$ & $\begin{array}{l}01,02,03, \\
046-048, \\
053,055, \\
06,07,08, \\
09,1,4\end{array}$ & & & & & $\begin{array}{c}\text { Processed } \\
\text { Food } \\
(\mathrm{PFO})\end{array}$ & $\begin{array}{l}01,02,03, \\
046-048, \\
053,055, \\
06,07,08, \\
09,1,4\end{array}$ \\
\hline \multirow[b]{2}{*}{$\begin{array}{l}\text { Minerals } \\
\text { Intensive }\end{array}$} & \multirow{2}{*}{$\begin{array}{l}27,28, \\
3,61,63, \\
661-663, \\
667,671, \\
68\end{array}$} & \multirow[b]{2}{*}{$\begin{array}{l}\text { Raw Mate- } \\
\text { rials }\end{array}$} & \multirow[b]{2}{*}{$\begin{array}{l}27,28,3- \\
33 \\
68\end{array}$} & & & $\begin{array}{l}\text { Minerals } \\
(\mathrm{MIN})\end{array}$ & $\begin{array}{l}27,28,3- \\
33\end{array}$ \\
\hline & & & & $\begin{array}{l}\text { Natural } \\
\text { resources }\end{array}$ & $\begin{array}{l}61,63 \\
661-663, \\
667,671, \\
68\end{array}$ & $\begin{array}{c}\text { Natural } \\
\text { resources } \\
(\mathrm{NRK})\end{array}$ & $\begin{array}{l}61,63, \\
661-663, \\
667,671, \\
68\end{array}$ \\
\hline \multirow{2}{*}{$\begin{array}{l}\text { Labor } \\
\text { intensive }\end{array}$} & \multirow{2}{*}{$\begin{array}{l}65,664- \\
666,81- \\
85,894 \\
895,899\end{array}$} & \multirow{2}{*}{$\begin{array}{l}\text { Labor } \\
\text { intensive }\end{array}$} & \multirow{2}{*}{$\begin{array}{l}66,82-85, \\
89\end{array}$} & $\begin{array}{l}\text { Unskilled } \\
\text { Labor }\end{array}$ & $\begin{array}{l}65,664- \\
666,793, \\
81-85, \\
894,895\end{array}$ & $\begin{array}{l}\text { Unskilled } \\
\text { Labor } \\
\text { (UNL) }\end{array}$ & $\begin{array}{l}65,664- \\
666,81- \\
85,894 \\
895\end{array}$ \\
\hline & & & & \multirow[b]{2}{*}{$\begin{array}{c}\text { Human } \\
\text { capital } \\
\text { intensive }\end{array}$} & \multirow{2}{*}{$\begin{array}{l}53,55,62, \\
64,67(- \\
671), 69, \\
76(-764), \\
78,791, \\
885,892, \\
896,897, \\
898\end{array}$} & $\begin{array}{l}\text { Skilled } \\
\text { Labor* } \\
(\mathrm{SKL})\end{array}$ & $\begin{array}{l}52,53,55, \\
59,896, \\
897,899\end{array}$ \\
\hline \multirow{3}{*}{$\begin{array}{l}\text { Capital } \\
\text { intensive }\end{array}$} & \multirow{3}{*}{$\begin{array}{l}5,62,64, \\
67,69,7, \\
87,88, \\
892,896, \\
897,891, \\
893\end{array}$} & $\begin{array}{c}\text { Capital } \\
\text { intensive }\end{array}$ & $\begin{array}{l}61,62,65, \\
67,69,81\end{array}$ & & & $\begin{array}{c}\text { Capital } \\
\text { intensive } \\
(\mathrm{CAP})\end{array}$ & $\begin{array}{l}62,64,67, \\
69,76(- \\
764), 78, \\
791,891, \\
892,893\end{array}$ \\
\hline & & Chemicals & 5 & & $51,52,54$ & & \\
\hline & & Machinery & $7,87,88$ & $\begin{array}{l}\text { Technol- } \\
\text { ogy inten- } \\
\text { sive }\end{array}$ & $\begin{array}{l}71,72,73, \\
74,75, \\
764,77, \\
792,87, \\
881-884, \\
893\end{array}$ & $\begin{array}{l}\text { Technol- } \\
\text { ogy inten- } \\
\text { sive } \\
\text { (TEC) }\end{array}$ & $\begin{array}{l}58,71,72, \\
73,74,75, \\
764,77, \\
792,87, \\
88\end{array}$ \\
\hline
\end{tabular}

*We used both Marrewijck (2004) and Estervadeordal (1997) classification for this cluster. 
A3. Label and Sources of Variables

\begin{tabular}{|c|c|c|}
\hline Label & Content & Sources \\
\hline Population & Total Population & WDI (2004) \\
\hline Income pc & GDP per capita in power parity purchase (PPP) & $\begin{array}{l}\text { Pen WorldTables } \\
(2005)\end{array}$ \\
\hline Capital & Capital per Worker & $\begin{array}{l}\text { Easterly and Lev- } \\
\text { ine (1999) \& Kraay } \\
\text { and al. (2000) }\end{array}$ \\
\hline Land & Land arable per labor force & WDI (2004) \\
\hline Unskilled & $\begin{array}{l}\text { Proportion of the population over } 15 \text { years (non edu- } \\
\text { cated (or primary not completed) }\end{array}$ & $\begin{array}{l}\text { Barro and Lee } \\
(2000)\end{array}$ \\
\hline Primary & $\begin{array}{l}\text { Proportion of the population over } 15 \text { years primary } \\
\text { educated (completed) (or secondary not completed) }\end{array}$ & $\begin{array}{l}\text { Barro and Lee } \\
(2000)\end{array}$ \\
\hline High-Secondary & $\begin{array}{l}\text { Proportion of the population over } 15 \text { years High edu- } \\
\text { cated }\end{array}$ & $\begin{array}{l}\text { Barro and Lee } \\
(2000)\end{array}$ \\
\hline TFP & $\begin{array}{l}\text { The TFP is calculated un logs as the difference } \\
\text { between output and factor use: } \log T F P=\log \mathrm{Y}-a \log \\
L-b \log \mathrm{K} \text {, with } \mathrm{a}+\mathrm{b}>1\end{array}$ & $\begin{array}{l}\text { Calculate by author } \\
\text { from the dataset }\end{array}$ \\
\hline ICT & $\begin{array}{l}\text { principal component analysis on road networks, rail } \\
\text { networks, and paved road }\end{array}$ & $\begin{array}{l}\text { Calderon and Ser- } \\
\text { ven }(2004)\end{array}$ \\
\hline Infrastructure & $\begin{array}{l}\text { principal component analysis on personal computer, } \\
\text { internet host, telephone lines, and mobile phones }\end{array}$ & $\begin{array}{l}\text { Calderon and Ser- } \\
\text { ven (2004) }\end{array}$ \\
\hline Index WW & Index taking value 0 or 1 depending on liberalization & $\begin{array}{l}\text { Wacziarg \& Welch } \\
(2003)\end{array}$ \\
\hline Landlockness & Index taking value 0 or 1 depending on landlockness & CEPII (2005) \\
\hline Growth of Partners & Rate of GDP growth of weighed trade partners & CEPII (2005) \\
\hline
\end{tabular}


A4. Variance of Variables

\begin{tabular}{|c|c|c|c|c|}
\hline & & Between & Within & $\begin{array}{c}\text { Between/ } \\
\text { Within }\end{array}$ \\
\hline \multicolumn{5}{|l|}{ Net Exports } \\
\hline & Agriculture (AGR) & 0,21 & 0,06 & 3,48 \\
\hline & Pr. Food (PFO) & 0,15 & 0,04 & 3,43 \\
\hline & Minerals (MIN) & 0,10 & 0,03 & 3,91 \\
\hline & Nat. Resources (NRK) & 0,14 & 0,02 & 5,53 \\
\hline & Unskilled Labor (UNL) & 0,11 & 0,04 & 2,64 \\
\hline & Skilled Labor (SKL) & 0,05 & 0,02 & 2,41 \\
\hline & Capital (CAP) & 0,17 & 0,05 & 3,38 \\
\hline & Technology (TEC) & 0,21 & 0,08 & 2,55 \\
\hline \multicolumn{5}{|l|}{ Predicted Probability } \\
\hline & Agriculture (AGR) & 0,27 & 0,04 & 6,81 \\
\hline & Pr. Food (PFO) & 0,27 & 0,06 & 4,23 \\
\hline & Minerals (MIN) & 0,25 & 0,09 & 2,82 \\
\hline & Nat. Resources (NRK) & 0,31 & 0,07 & 4,46 \\
\hline & Unskilled Labor (UNL) & 0,31 & 0,10 & 3,13 \\
\hline & Skilled Labor (SKL) & 0,26 & 0,05 & 5,18 \\
\hline & Capital (CAP) & 0,26 & 0,05 & 4,98 \\
\hline & Technology (TEC) & 0,29 & 0,04 & 7,39 \\
\hline \multicolumn{5}{|l|}{ Explanatory Variables } \\
\hline & Income p.c. & 0,94 & 0,18 & 5,08 \\
\hline \multirow[t]{7}{*}{ New Determinants } & Population & 1,47 & 0,15 & 10,06 \\
\hline & TFP & 0,26 & 0,15 & 1,72 \\
\hline & Growth Partners & 0,05 & 0,08 & 0,56 \\
\hline & Infrastructure & 1,31 & 0,22 & 5,89 \\
\hline & ICT & 0,88 & 0,72 & 1,23 \\
\hline & Land & 1,14 & 0,11 & 10,67 \\
\hline & Capital & 1,32 & 0,21 & 6,37 \\
\hline \multirow[t]{3}{*}{ Factor's Endowments } & Unskilled & 1,38 & 0,24 & 5,76 \\
\hline & Primary & 0,52 & 0,18 & 2,88 \\
\hline & Highly \& Secondary & 0,78 & 0,23 & 3,34 \\
\hline
\end{tabular}


A5. Expected Results

\begin{tabular}{lcccccccc}
\hline & 1 & 2 & 3 & 4 & 5 & 6 & 7 & 8 \\
\hline $\begin{array}{l}\text { Probability of Being a } \\
\text { Net Exporter }\end{array}$ & AGR & PFO & MIN & NRK & UNL & SKL & CAP & TEC \\
Capital & - & - & + & + & - & - & + & + \\
Land & + & + & & + & - & - & - & - \\
Unskilled & + & + & + & + & + & - & & - \\
Primary & + & + & + & + & + & & + & \\
High-Secondary & - & - & - & - & - & + & + & + \\
Income p.c. & + & + & - & & + & - & - & - \\
Population & - & - & - & + & + & + & + & + \\
TFP & - & - & - & + & + & + & + & + \\
ICT & & & & & + & + & + & + \\
Infrastructure & & & & & + & + & + & + \\
\hline
\end{tabular}

Cluster of Net Exporters

\begin{tabular}{|c|c|c|c|c|c|c|c|c|}
\hline & 1 & 2 & 3 & 4 & 5 & 6 & 7 & 8 \\
\hline $\operatorname{Ln}\left(c+\frac{X-M}{P I B}\right)$ & AGR & $\mathrm{PFO}$ & MIN & NRK & UNL & SKL & CAP & TEC \\
\hline Income p.c. & - & - & - & - & - & - & - & - \\
\hline $\begin{array}{c}\text { Population } \\
\text { TFP }\end{array}$ & - & - & - & - & - & - & - & - \\
\hline \multicolumn{9}{|l|}{ Partner Growth } \\
\hline Landlockness & - & - & - & - & - & - & - & - \\
\hline Infrastructure & + & + & + & + & + & + & + & + \\
\hline ICT & + & + & + & + & + & + & + & + \\
\hline Openness & + & + & + & + & + & + & + & + \\
\hline
\end{tabular}

Cluster of Net Importers

\begin{tabular}{ccccccccc}
\hline & 1 & 2 & 3 & 4 & 5 & 6 & 7 & 8 \\
\hline$L n\left(c+\frac{X-M}{P I B}\right)$ & AGR & PFO & MIN & NRK & UNL & SKL & CAP & TEC \\
Income p.c. & + & + & + & + & + & + & + & + \\
Population & + & + & + & + & + & + & + & + \\
TFP & & & & & & & & \\
Partner Growth & & & & & & & & \\
Landlockness & + & + & + & + & + & + & + & + \\
Infrastructure & - & - & - & - & - & - & - & - \\
ICT & - & - & - & - & - & - & - & - \\
Openness & - & - & - & - & - & - & - & - \\
\hline
\end{tabular}



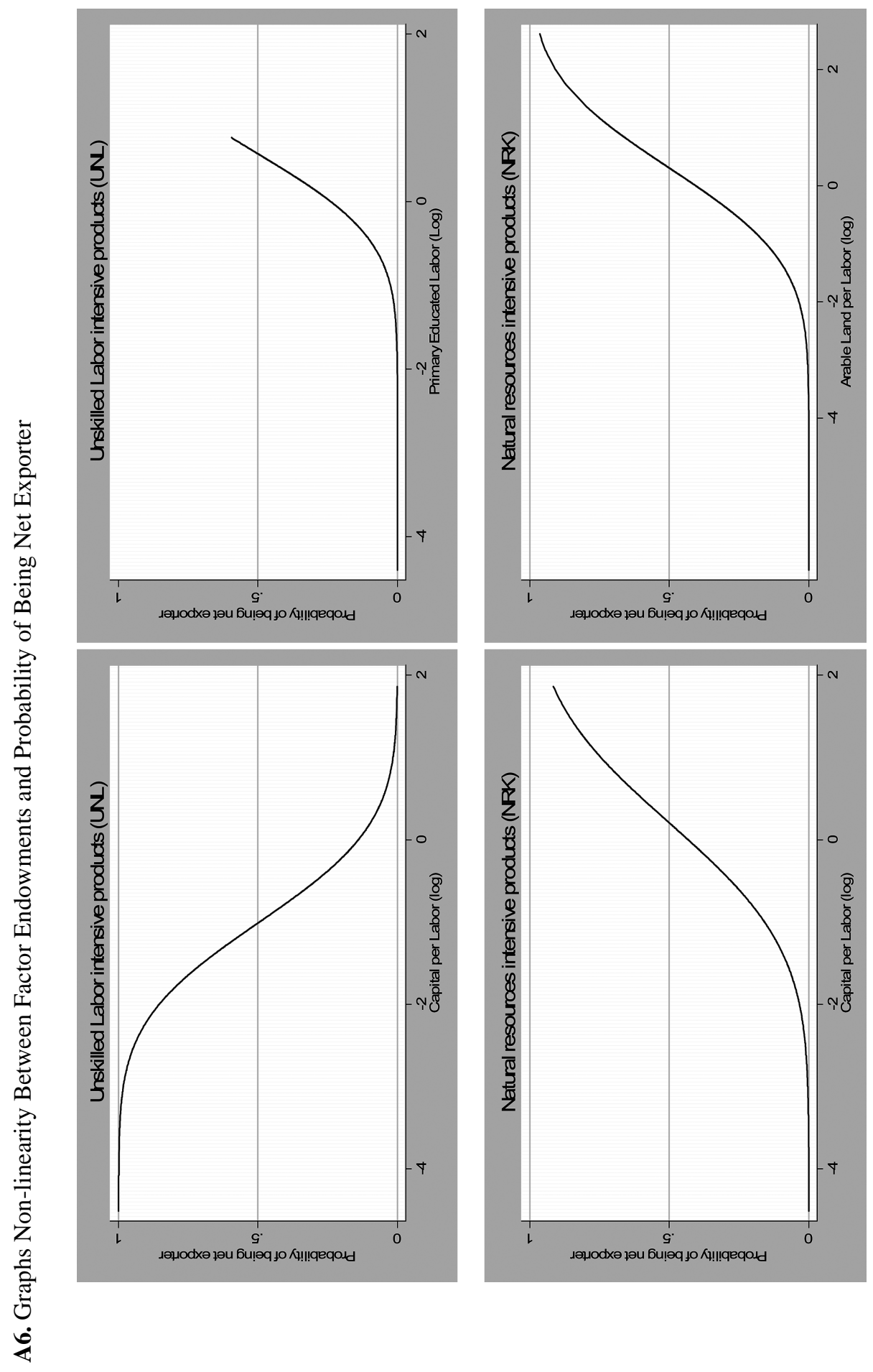

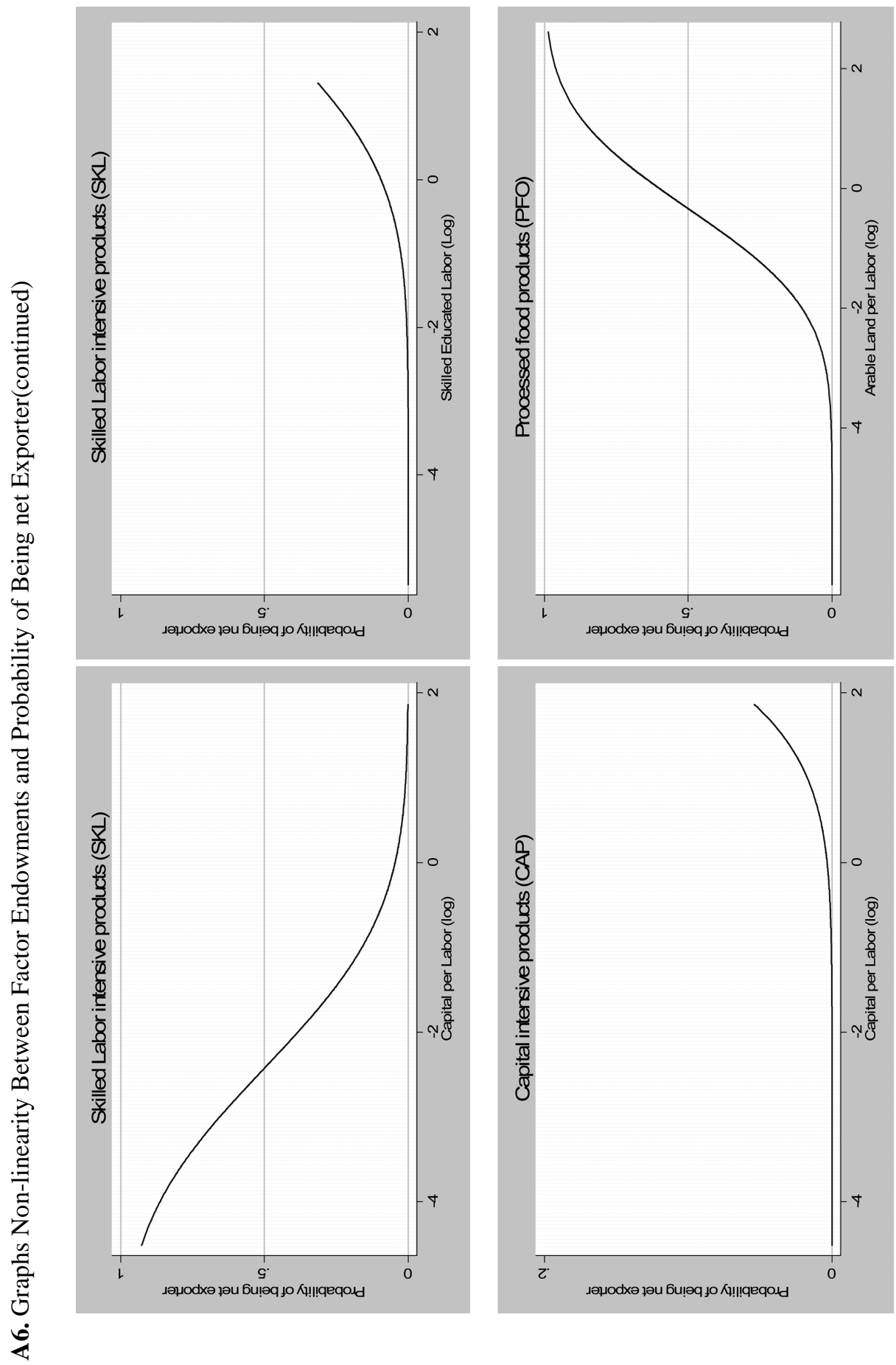
A7. Determinants of Comparative Advantage: Probit on the Probability of Being a Net Exporter of Each Commodity Cluster for 1960-1980 and 1980-2000.

\begin{tabular}{|c|c|c|c|c|c|c|c|c|}
\hline $\begin{array}{l}\text { Probability of being } \\
\text { a net exporter }\end{array}$ & AGR & AGR & PFO & PFO & MIN & MIN & NRK & NRK \\
\hline Period & $\begin{array}{l}1960- \\
1980\end{array}$ & $\begin{array}{l}1980- \\
2000\end{array}$ & $\begin{array}{l}1960- \\
1980\end{array}$ & $\begin{array}{l}1980- \\
2000\end{array}$ & $\begin{array}{l}1960- \\
1980\end{array}$ & $\begin{array}{l}1980- \\
2000\end{array}$ & $\begin{array}{l}1960- \\
1980\end{array}$ & $\begin{array}{l}1980- \\
2000\end{array}$ \\
\hline Capital & $\begin{array}{r}\mathbf{- 0 . 2 7 5}^{\mathrm{a}} \\
(2.93)\end{array}$ & $\begin{array}{l}0.074 \\
(0.80)\end{array}$ & $\begin{array}{r}-\mathbf{- 0 . 4 3 6}^{\mathrm{a}} \\
(4.11)\end{array}$ & $\begin{array}{c}-0.042 \\
(0.36)\end{array}$ & $\begin{array}{l}\mathbf{0 . 3 2 6}^{\mathrm{a}} \\
(2.98)\end{array}$ & $\begin{array}{l}\mathbf{0 . 7 6 6}^{\mathrm{a}} \\
(5.27)\end{array}$ & $\begin{array}{l}\mathbf{0 . 1 8 6}^{\mathrm{b}} \\
(2.12)\end{array}$ & $\begin{array}{l}\mathbf{0 . 6 9 7}^{\mathrm{a}} \\
(4.93)\end{array}$ \\
\hline Land & $\begin{array}{l}0.078 \\
(1.60)\end{array}$ & $\begin{array}{l}\mathbf{0 . 2 2 2}^{\mathrm{a}} \\
(3.76)\end{array}$ & $\begin{array}{l}\mathbf{0 . 4 2 9}^{\mathrm{a}} \\
(5.35)\end{array}$ & $\begin{array}{l}\mathbf{0 . 3 5 4} 4^{\mathrm{a}} \\
(5.87)\end{array}$ & $\begin{array}{l}0.037 \\
(0.79)\end{array}$ & $\begin{array}{l}-0.127^{\mathrm{a}} \\
(3.29)\end{array}$ & $\begin{array}{l}\mathbf{0 . 2 1 1}^{\mathrm{a}} \\
(4.52)\end{array}$ & $\begin{array}{l}\mathbf{0 . 4 4 6}^{\mathrm{a}} \\
(6.62)\end{array}$ \\
\hline Unskilled & $\begin{array}{c}-0.190^{\mathrm{a}} \\
(3.30)\end{array}$ & $\begin{array}{l}-0.078 \\
(1.50)\end{array}$ & $\begin{array}{l}0.147 \\
(1.50)\end{array}$ & $\begin{array}{l}\mathbf{0 . 1 1 2}^{\mathrm{c}} \\
(1.85)\end{array}$ & $\begin{array}{c}-0.038 \\
(0.51)\end{array}$ & $\begin{array}{l}\mathbf{0 . 1 6 5}^{b} \\
(2.13)\end{array}$ & $\begin{array}{l}\mathbf{0 . 2 0 7}^{\mathrm{b}} \\
(2.20)\end{array}$ & $\begin{array}{l}\mathbf{0 . 2 3 7}^{\mathrm{a}} \\
(3.59)\end{array}$ \\
\hline Primary & $\begin{array}{l}-0.065 \\
(0.71)\end{array}$ & $\begin{array}{l}-0.152 \\
(1.57)\end{array}$ & $\begin{array}{l}\mathbf{0 . 5 3 8}^{\mathrm{a}} \\
(3.24)\end{array}$ & $\begin{array}{l}\mathbf{0 . 1 8 6}^{\mathrm{c}} \\
(1.95)\end{array}$ & $\begin{array}{c}-0.266^{\mathrm{c}} \\
(1.74)\end{array}$ & $\begin{array}{l}-0.095 \\
(0.63)\end{array}$ & $\begin{array}{l}0.056 \\
(0.32)\end{array}$ & $\begin{array}{l}\mathbf{0 . 2 3 6} \\
(1.78)\end{array}$ \\
\hline High-Secondary & $\begin{array}{c}-0.098 \\
(1.11)\end{array}$ & $\begin{array}{r}-\mathbf{0 . 2 4 0} \\
(2.32)\end{array}$ & $\begin{array}{l}0.295^{\mathrm{c}} \\
(1.81)\end{array}$ & $\begin{array}{l}0.168 \\
(1.57)\end{array}$ & $\begin{array}{l}0.488^{\mathrm{a}} \\
(3.77)\end{array}$ & $\begin{array}{l}0.191 \\
(1.33)\end{array}$ & $\begin{array}{c}0.303 b \\
(2.33)\end{array}$ & $\begin{array}{l}0.186 \\
(1.38)\end{array}$ \\
\hline Income p.c. & $\begin{array}{l}0.054 \\
(0.33)\end{array}$ & $\begin{array}{l}-0.193 \\
(1.19)\end{array}$ & $\begin{array}{c}\mathbf{0 . 3 8 5}^{\mathrm{b}} \\
(2.30)\end{array}$ & $\begin{array}{l}0.076 \\
(0.41)\end{array}$ & $\begin{array}{c}-0.144 \\
(0.88)\end{array}$ & $\begin{array}{c}-0.518^{b} \\
(2.56)\end{array}$ & $\begin{array}{l}0.003 \\
(0.02)\end{array}$ & $\begin{array}{c}-0.278 \\
(1.38)\end{array}$ \\
\hline Population & $\begin{array}{r}-0.007 \\
(0.21)\end{array}$ & $\begin{array}{l}-0.032 \\
(1.06)\end{array}$ & $\begin{array}{l}0.012 \\
(0.32)\end{array}$ & $\begin{array}{c}\mathbf{- 0 . 0 5 9}^{\mathrm{c}} \\
(1.79)\end{array}$ & $\begin{array}{c}-0.010 \\
(0.30)\end{array}$ & $\begin{array}{l}\mathbf{0 . 0 6 5}^{\text {b }} \\
(2.17)\end{array}$ & $\begin{array}{l}0.014 \\
(0.44)\end{array}$ & $\begin{array}{l}0.001 \\
(0.04)\end{array}$ \\
\hline TFP & $\begin{array}{c}-0.240 \\
(0.74)\end{array}$ & $\begin{array}{l}-0.037 \\
(0.25)\end{array}$ & $\begin{array}{l}-0.147 \\
(0.47)\end{array}$ & $\begin{array}{c}0.521 \mathrm{a} \\
(3.11)\end{array}$ & $\begin{array}{c}-0.390 \\
(1.27)\end{array}$ & $\begin{array}{c}-\mathbf{0 . 2 6 8} \\
(1.70)\end{array}$ & $\begin{array}{l}0.150 \\
(0.50)\end{array}$ & $\begin{array}{l}0.056 \\
(0.32)\end{array}$ \\
\hline ICT & $\begin{array}{l}1.127^{\mathrm{b}} \\
(2.32)\end{array}$ & $\begin{array}{l}-0.011 \\
(0.40)\end{array}$ & $\begin{array}{c}\mathbf{- 1 . 2 8 9}^{b} \\
(2.34)\end{array}$ & $\begin{array}{c}-0.038 \\
(1.24)\end{array}$ & $\begin{array}{c}-\mathbf{2 . 1 7 2}^{\mathrm{a}} \\
(3.88)\end{array}$ & $\begin{array}{l}0.001 \\
(0.04)\end{array}$ & $\begin{array}{c}-0.145 \\
(0.32)\end{array}$ & $\begin{array}{l}0.012 \\
(0.42)\end{array}$ \\
\hline Infrastructure & $\begin{array}{r}-0.187 \\
(1.49)\end{array}$ & $\begin{array}{l}0.150 \\
(1.28)\end{array}$ & $\begin{array}{l}0.490^{\mathrm{a}} \\
(3.61)\end{array}$ & $\begin{array}{l}0.165 \\
(1.49)\end{array}$ & $\begin{array}{l}0.226^{\mathrm{c}} \\
(1.84)\end{array}$ & $\begin{array}{c}\mathbf{- 0 . 3 5 3}^{\mathrm{a}} \\
(2.85)\end{array}$ & $\begin{array}{l}-0.122 \\
(1.02)\end{array}$ & $\begin{array}{r}-0.318^{\mathrm{a}} \\
(2.89)\end{array}$ \\
\hline Regional Dummies & Yes & Yes & Yes & Yes & Yes & Yes & Yes & Yes \\
\hline Observations & 213 & 248 & 212 & 249 & 202 & 241 & 214 & 251 \\
\hline
\end{tabular}


A7. Determinants of Comparative Advantage: Probit on the Probability of Being a Net Exporter of Each Commodity Cluster for 1960-1980 and 1980-2000 (continued).

\begin{tabular}{|c|c|c|c|c|c|c|c|c|}
\hline $\begin{array}{c}\text { Probability of } \\
\text { being a net } \\
\text { exporter }\end{array}$ & UNL & UNL & SKL & SKL & CAP & CAP & TEC & TEC \\
\hline Period & $\begin{array}{l}1960- \\
1980\end{array}$ & $\begin{array}{l}\text { 1980- } \\
2000\end{array}$ & $\begin{array}{l}1960- \\
1980\end{array}$ & $\begin{array}{l}1980- \\
2000\end{array}$ & $\begin{array}{c}1960- \\
1980\end{array}$ & $\begin{array}{l}\text { 1980- } \\
2000\end{array}$ & $\begin{array}{c}1960 \\
-1980\end{array}$ & $\begin{array}{c}1980 \\
-2000\end{array}$ \\
\hline Capital & $\begin{array}{c}-\mathbf{0 . 2 4 0} \\
(4.51)\end{array}$ & $\begin{array}{c}\mathbf{- 0 . 7 9 7} \\
(4.86)\end{array}$ & $\begin{array}{c}\mathbf{- 0 . 1 0 9}^{\mathrm{a}} \\
(3.62)\end{array}$ & $\begin{array}{c}-0.006 \\
(0.16)\end{array}$ & $\begin{array}{c}\mathbf{- 0 . 0 0 0}^{b} \\
(2.48)\end{array}$ & $\begin{array}{l}\mathbf{0 . 0 8 4}^{\mathrm{a}} \\
(2.74)\end{array}$ & $\begin{array}{c}0.000000 \\
(0.22)\end{array}$ & $\begin{array}{c}0.000077 \\
(0.76)\end{array}$ \\
\hline Land & $\begin{array}{c}\mathbf{- 0 . 0 4 8}^{\mathrm{c}} \\
(1.85)\end{array}$ & $\begin{array}{l}\mathbf{0 . 1 2 6}^{\mathrm{a}} \\
(2.82)\end{array}$ & $\begin{array}{c}-0.044^{\mathrm{a}} \\
(4.01)\end{array}$ & $\begin{array}{c}-0.005 \\
(0.51)\end{array}$ & $\begin{array}{l}0.000^{\mathrm{b}} \\
(2.11)\end{array}$ & $\begin{array}{l}0.017^{\mathrm{c}} \\
(1.69)\end{array}$ & $\begin{array}{c}-\mathbf{0 . 0 0 0 0 0 0} 0^{\mathrm{b}} \\
(2.04)\end{array}$ & $\begin{array}{c}-\mathbf{0 . 0 0 0 0 5 9} 9^{b} \\
(2.10)\end{array}$ \\
\hline Unskilled & $\begin{array}{r}-0.015 \\
(0.59)\end{array}$ & $\begin{array}{l}\mathbf{0 . 4 4 0}^{\mathrm{a}} \\
(4.49)\end{array}$ & $\begin{array}{c}-0.022^{\mathrm{b}} \\
(2.25)\end{array}$ & $\begin{array}{c}\mathbf{- 0 . 0 3 4}^{\mathrm{b}} \\
(2.43)\end{array}$ & $\begin{array}{c}-\mathbf{- 0 . 0 0 0}^{\mathrm{a}} \\
(2.75)\end{array}$ & $\begin{array}{c}\mathbf{- 0 . 0 2 3}^{\mathrm{b}} \\
(2.28)\end{array}$ & $\begin{array}{c}-0.000000 \\
(1.39)\end{array}$ & $\begin{array}{c}0.000001 \\
(0.03)\end{array}$ \\
\hline Primary & $\begin{array}{c}\mathbf{0 . 1 3 4}^{\mathrm{b}} \\
(2.52)\end{array}$ & $\begin{array}{l}\mathbf{0 . 6 4 8}^{\mathrm{a}} \\
(5.32)\end{array}$ & $\begin{array}{l}0.106^{\mathrm{a}} \\
(3.24)\end{array}$ & $\begin{array}{l}0.019 \\
(0.76)\end{array}$ & $\begin{array}{l}0.000^{\mathrm{b}} \\
(2.04)\end{array}$ & $\begin{array}{l}0.017 \\
(0.61)\end{array}$ & $\begin{array}{c}0.000000 \\
(0.89)\end{array}$ & $\begin{array}{c}0.000056 \\
(0.94)\end{array}$ \\
\hline $\begin{array}{c}\text { High- } \\
\text { Secondary }\end{array}$ & $\begin{array}{c}\mathbf{- 0 . 1 8 2} 2^{a} \\
(3.60)\end{array}$ & $\begin{array}{l}0.910^{\mathrm{a}} \\
(4.50)\end{array}$ & $\begin{array}{l}\mathbf{0 . 0 4 9}^{\mathrm{b}} \\
(2.10)\end{array}$ & $\begin{array}{l}\mathbf{0 . 1 0 6}^{\mathrm{b}} \\
(2.38)\end{array}$ & $\begin{array}{l}0.000^{\mathrm{b}} \\
(2.50)\end{array}$ & $\begin{array}{c}-0.055^{\mathrm{c}} \\
(1.81)\end{array}$ & $\begin{array}{c}0.000000 \\
(0.62)\end{array}$ & $\begin{array}{c}\mathbf{0 . 0 0 0 2 1 3}^{b} \\
(2.14)\end{array}$ \\
\hline Income p.c. & $\begin{array}{l}0.072 \\
(0.84)\end{array}$ & $\begin{array}{l}\mathbf{0 . 7 2 3}^{\mathrm{a}} \\
(3.59)\end{array}$ & $\begin{array}{l}0.015 \\
(0.41)\end{array}$ & $\begin{array}{r}-0.067 \\
(1.24)\end{array}$ & $\begin{array}{l}-0.000 \\
(1.10)\end{array}$ & $\begin{array}{c}-0.034 \\
(0.83)\end{array}$ & $\begin{array}{c}-\mathbf{0 . 0 0 0 0 0 0 ^ { c }} \\
(1.88)\end{array}$ & $\begin{array}{c}-0.000221 \\
(1.49)\end{array}$ \\
\hline Population & $\begin{array}{l}\mathbf{0 . 1 4 1}^{\mathrm{a}} \\
(6.80)\end{array}$ & $\begin{array}{l}\mathbf{0 . 1 8 6}^{\mathrm{a}} \\
(4.34)\end{array}$ & $\begin{array}{l}\mathbf{0 . 0 4 4 ^ { \mathrm { a } }} \\
(5.64)\end{array}$ & $\begin{array}{c}\mathbf{0 . 0 3 9}^{\mathrm{a}} \\
(5.70)\end{array}$ & $\begin{array}{l}\mathbf{0 . 0 0 0}^{\mathrm{a}} \\
(3.62)\end{array}$ & $\begin{array}{c}\mathbf{0 . 0 3 1}^{\mathrm{a}} \\
(4.54)\end{array}$ & $\begin{array}{c}\mathbf{0 . 0 0 0 0 0 0}^{\mathrm{a}} \\
(5.31)\end{array}$ & $\begin{array}{c}\mathbf{0 . 0 0 0 0 4 6}^{\mathrm{a}} \\
(2.93)\end{array}$ \\
\hline TFP & $\begin{array}{l}\mathbf{0 . 2 6 3}^{\mathrm{c}} \\
(1.68)\end{array}$ & $\begin{array}{l}\mathbf{0 . 6 6 7} \\
(3.82)\end{array}$ & $\begin{array}{l}-0.035 \\
(0.64)\end{array}$ & $\begin{array}{l}0.122^{b} \\
(2.37)\end{array}$ & $\begin{array}{l}\mathbf{0 . 0 0 0}^{\mathrm{a}} \\
(3.40)\end{array}$ & $\begin{array}{l}\mathbf{0 . 1 0 0}^{\mathrm{a}} \\
(2.69)\end{array}$ & $\begin{array}{c}0.000000 \\
(0.89)\end{array}$ & $\begin{array}{c}-0.000039 \\
(0.47)\end{array}$ \\
\hline ICT & $\begin{array}{l}1.458^{\mathrm{a}} \\
(5.42)\end{array}$ & $\begin{array}{c}-0.103^{\mathrm{a}} \\
(3.23)\end{array}$ & $\begin{array}{l}0.147 \\
(1.35)\end{array}$ & $\begin{array}{c}-0.002 \\
(0.39)\end{array}$ & $\begin{array}{l}\mathbf{0 . 0 0 0}^{\mathrm{a}} \\
(2.88)\end{array}$ & $\begin{array}{c}-0.002 \\
(0.26)\end{array}$ & $\begin{array}{c}0.000000 \\
(1.45)\end{array}$ & $\begin{array}{c}\mathbf{0 . 0 0 0 0 2 0}^{\mathrm{c}} \\
(1.95)\end{array}$ \\
\hline Infrastructure & $\begin{array}{l}-0.025 \\
(0.35)\end{array}$ & $\begin{array}{l}0.229 \\
(1.54)\end{array}$ & $\begin{array}{l}0.026 \\
(0.87)\end{array}$ & $\begin{array}{l}\mathbf{0 . 0 8 4}^{\mathrm{a}} \\
(2.93)\end{array}$ & $\begin{array}{c}-0.000^{b} \\
(2.38)\end{array}$ & $\begin{array}{l}0.036 \\
(1.17)\end{array}$ & $\begin{array}{c}\mathbf{0 . 0 0 0 0 0 0}^{\mathrm{a}} \\
(4.07)\end{array}$ & $\begin{array}{c}\mathbf{0 . 0 0 0 1 4 3}^{\mathrm{c}} \\
\quad(1.65)\end{array}$ \\
\hline $\begin{array}{l}\text { Regional } \\
\text { Dummies }\end{array}$ & Yes & Yes & Yes & Yes & Yes & Yes & Yes & Yes \\
\hline Observations & 213 & 248 & 213 & 249 & 214 & 242 & 213 & 241 \\
\hline
\end{tabular}

a: means significant at $1 \%$, b: means significant at $5 \%$ and c: means significant at $10 \%$ 


\section{References}

Antweiler, W., Trefler, D.(2002), "Increased Return and All That: a View from Trade", The American Economic Review, Vol. 92.

Balassa, B., Bauwens, L.(1988), "Changing Trade Patterns in Manufacturing Goods: an Econometric Investigation", Amsterdam.

Bosworth G., Collins S.(2003), "The Empirics of Growth: an Update" Brookings Paper on Economic Activity.

Bougheas, S., Demetriades, P., Mamuneas, T.(2000), "Infrastructure, Specialization and Economic Growth", The Canadian Journal of Economics, Vol. 337.

Bowen, H. P., Leamer, E., Sveikauskas, L.(1987), "Multi-country, Multi-factor Test of the Factor Abundance Theory", The American Economic Review, Vol. 77.

Davis, D. Weinstein, D., Bradford, S., Shimpo, K.(1997), "Using International and Japanese Regional Data to Determine When the Factor Abundance Theory of Trade Works", American Economic Review, Vol. 87.

Davis, D., Weinstein, D.(2001), "An Account of Global Factor Trade", American Economic Review, Vol. 91.

Deardorff, A. V.(1980), "The General Validity of the Law of Comparative Advantage", Journal of Political Economy, Vol. 88.

Deardorff, A. V.(1984), "Testing Trade Theories and Predicting Trade Flows", Handbook of International Economics, Vol. 1.

Deardorff, A. V.(1994), "Exploring the Limits of Comparative Advantage", Review of World Economics, Vol. 130.

Estervadeordal, A.(1997), "Measuring Protection in the Early Twentieth Century", European Review of Economic History, Vol. 1.

Estervadeordal, A., Taylor, A.M.(2002), "A Century of Missing Trade", American Economic Review, Vol. 92.

Estervadeordal, A. Taylor, A.M.(2002), "Testing Trade Theory in Ohlin's Time" In Ronald Findlay, Lars Jonung and Mats Lundhal, eds., Bertil Ohlin: a Centennial Celebration: 1899-1999: Cambridge MIT Press.

Ethier, W. J.(1974), "Some of the Theorems of International Trade with Many Goods and Factors", Journal of International Economics, Vol. 4.

Ethier, W J., Svensson, L.E.O.(1986), "The Theorems of International Trade with Factor Mobility", Journal of International Economics, Vol. 20.

Feenstra, R.(2004), "Advanced International Trade: Theory and Evidence", Princeton University Press.

Forstner, H., Balance, R.(1990), "Competing in a Global Economy: an Empirical Studies on Specialisation and Trade in Manufactures", London.

Gaisford, J. D.(1995), "International Capital Mobility, the Factor Contents of Trade and Leontief Paradoxes", Journal of International Economics, Vol. 5.

Harrigan J.(1997), “Technology, Factor supplies and International Specialization: 
Estimating the neo classical model", American Economic Review, Vol. 87.

Harrigan, J., Zakrajsek, E.(2000), "Factor Supplies and Specialization in the World Economy", Mimeo, International Research Department Federal Reserve of New York Head, K., Ries, J.(2001), "Increasing returns versus National Product Differentiation as an Explanation for the Patterns of US-Canada Trade", American Economic Review, Vol. 91.

Hein, S.(1992), "Trade Strategies and the Dependency Hypothesis: A Comparison of Policy, Foreign Investment, and Economic Growth in Latin America and East Asia", Economic Development and Cultural Change, Vol. 40.

Hunter, L.C., Markusen, J.R.(1988), "Per Capita Income as Determinant of Trade", in R. Feenstra ed. Empirical Methods for International Trade, MIT Press Cambridge NA.

Jones, R., Beladi, H., Marjit, S.(1998), “The Three Faces of Factor Intensities”, Journal of International Economics, Vol. 48.

Jones, R.(2000), "Globalization and the Theory of Input Trade", Cambridge MIT Press

Leamer, E.(1980), "The Leontief Paradox Reconsidered”, Journal of Political Economy, Vol. 88

Leamer, E.(1984), "Sources of International Comparative Advantage: Theory and Evidence", Cambridge: MIT Press.

Leamer, E.(1987), "Paths of Development in the 3-factor, N-Good General Equilibrium Mode", Journal of Political Economy, Vol. 95.

Leamer, E.(1987), "Measures of Openness", in R. Baldwin (ed.) "Trade Policy Issues and Empirical Analysis", Chicago Press.

Leamer, E. Levinsohn, J.(1995), "International Trade Theory: the Evidence", Chapter 3 In Handbook of International Economics, Vol. 3, Amsterdam North Holland.

Leamer, E. Rodriguez, S. Schott, P.K.(1999), "Does Natural Resources Abundance Increase Latin American Income Inequality?", Journal of Development Economics, Vol. 59.

Lederman, D. Xu, L.C.(2006), "Comparative Advantage and Trade Intensity: Are Traditional Endowment Destiny?", in Natural Resources: Neither Curse nor Destiny.Daniel Lederman and William F. Maloney, editors, Stanford, CA: Stanford University Press.

Leontief, W.W.(1956), "Factor Proportions and the Structure of American Trade", Review of Economics and Statistics.

Markusen J. (1986), "Explaining the Volume of Trade: an Eclectic Approach", American Economic Review, Vol. 76.

Markusen, J. Melvin, J.(1981), "Trade, Factor Prices and Gains from Trade with increasing Returns to Scale", Canadian Journal of Economics, Vol. 14

Marrewijck C., Hinloopen J.(2004), "Dynamics of Chinese Comparative Advantage", Timbergen Institute Discussion Paper 034/2.

Minford, P.(1998), “A labour-Based Theory of International Trade" in J.Black, A.I. MacBeans (eds.), Cause of Changes in the Structural of International Changes 196085 Basingstoke. 
Neary, P.(2003), "Competitive versus Comparative Advantage" World Economy, Vol. 26. Santos-Paulino, A., Thirwall, A.P.(2004), "The Impact of Trade Liberalization on Exports, Imports and the Balance of Payments of Developing Countries", The Economic Journal, Vol.114.

Schott, P.(2003), "One Size Fits All? Hecksher-Ohlin Specialization in Global Production", American Economic Review, Vol. 93.

Schott, P.(2004), “Across Product versus Within-Product Specialisation in International Trade", Quarterly Journal of Economics, Vol. 119.

Spilimbergo, A., Londono, JL. Székely, M. (1999), "Income Distribution, Factor Endowments, and Trade Openness", Journal of Development Economics, Vol. 59.

Travis, W.P.(1964), "The Theory of Trade and Protection", Cambridge, Harvard University Press.

Trefler, D.(1995), "The case of the Missing Trade and Other Mysteries", The American Economic Review, Vol. 85.

Wacziarg, R., Welch. K.H.(2003) "Trade Liberalization and Growth: New Evidence", NBER Working Papers, n 10152.

Wood, A.(1994), "Give Hecksher and Ohlin a Chance!” Review of World Economics, Vol. 130.

Wood, A.(1995), "North-South Trade Employment and Inequality", Clarendon press oxford. 